\title{
Naturally Occurring Diterpenoid Dimers: Source, Biosynthesis, Chemistry and Bioactivities
}

Authors

Affiliation
Li-Gen Lin, Carolina Oi Lam Ung, Zhe-Ling Feng, Li Huang, Hao Hu

State Key Laboratory of Quality Research in Chinese Medicine, Institute of Chinese Medical Sciences, University of Macau, Macau, PR China

Key words
diterpenoid dimers
structure
source
biosynthesis
synthesis
bioactivities

received revised April 13, 2016 July 14, 2016 accepted August 1, 2016

Bibliography

Dol http://dx.doi.org/

10.1055/s-0042-114573

Published online August 19,

2016

Planta Med 2016; 82:

1309-1328 @ Georg Thieme Verlag KG Stuttgart · New York . ISSN 0032-0943

\section{Correspondence}

\section{Dr. Li-Gen Lin}

State Key Laboratory of Quality Research in Chinese Medicine Institute of Chinese Medical Sciences

University of Macau

Avenida da Universidade

Taipa 999078

Macau

PR China

Phone: +85388228041

Fax: +85328841358

ligen!@umac.mo

\section{Abstract \\ $\nabla$}

Diterpenoid dimers are rare in nature and mainly found in higher plants including the families Acanthaceae, Annonaceae, Asteraceae, Calceolariaceae, Chrysobalanaceae, Cupressaceae, Euphorbiaceae, Fabaceae, Lamiaceae, Liliaceae, Meliaceae, Rhizophoraceae, Taxaceae, Velloziaceae, and Zingiberaceae. In addition, a few diterpenoid dimers have been also reported from fungi (Psathyrellaceae), liverworts (Scapaniaceae), and a gorgonian (Gorgoniidae). They feature a wide variety of structures due to different core skeletons, linkage patterns, substituents, and configurations. Accordingly, diterpenoid dimers exhibit a broad range of bioactivities, including cytotoxic, anti-inflammatory, antimicrobial, antimalarial,

\section{Introduction}

$\nabla$

Diterpenoids are a structurally diverse class of natural products, consisting of four isoprene units to form a 20-carbon backbone. Based on their core structures, diterpenoids can be classified into linear, macrocyclic, bicyclic, tricyclic, tetracyclic and pentacyclic types [1]. Naturally occurring diterpenoids are always found in a polyoxygenated form: i) with hydroxyl groups, which are often esterified by aliphatic or aromatic acids, or etherified by alcohols; ii) with formyl and carbonyl groups, which have often reacted with hydroxyl groups to form hemiacetal or acetal moieties; or iii) with carboxyl groups, which often form esters or lactones through reaction with alcohols. Moreover some diterpenoids have been found with opened and rearranged ring structures. Diterpenoids exhibit various biological activities such as cytotoxic, anti-microbial, and anti-inflammatory properties, and have been identified as active principles in some traditional medicines $[2,3]$. Due to their structural diversity and broad bioac- and antifouling properties, which have attracted more and more research interests in the past decades. This review with 176 metabolites from 109 references provides a comprehensive and up-todate overview of the source, biosynthesis, structure, synthesis, and bioactivities of diterpenoid dimers.

\section{Abbreviations \\ $\nabla$ \\ DGAT: diacylglycerol 0 -acyltransferase \\ ECD: electronic circular dichroism \\ LPS: lipopolysaccharide \\ NO: $\quad$ nitric oxide \\ TRAIL: tumor necrosis factor-related apopto- sis-inducing ligand}

tivities, diterpenoids have attracted increasing research attentions, resulting in the identification of a growing number of compounds. Some of these compounds have been proven to be clinically effective. Taxol, for example, is an unusual diterpenoid discovered from Taxus brevifolia (Taxaceae), which inhibits the normal breakdown of microtubules during cell division, and is widely used in therapy against ovarian, breast, and lung cancer [4]. Salvinorin A, a diterpenoid isolated from Salvia divinorum, has psychoactive effects on humans, and has been used as an analgesic [5, 6].

Diterpenoid dimers are a rather uncommon subclass of diterpenoids, which are composed of two 20-carbon diterpenoid units linked through one or two $\mathrm{C}-\mathrm{C}$ bond, ester bond, ether bond or a ring moiety. On the basis of a literature search in various databases, including Google Scholar, SciFinder, Web of Science, and Scopus, using "diterpenoid dimer" or "tetraterpenoid" as key words, 176 naturally occurring diterpenoid dimers were retrieved, with various bioactivities including cyto- 
toxic, anti-inflammatory, antimicrobial, antimalarial, and antifouling activities ( $\bigcirc$ Table 1 ). Due to their structural complexity and the wide range of bioactivities, naturally occurring diterpenoid dimers have attracted more and more research interests in the past decades. Furthermore, the development of purification and structural elucidation methods, especially preparative HPLC and high resolution NMR, makes it now possible to identify compounds at trace amounts. Chiral HPLC dramatically accelerated the isolation of stereoisomers, especially those with complex structures like diterpenoid dimers [7-9]. In recent years, ECD calculations have been widely used to determine the absolute configurations of diterpenoid dimers [7,9-11]. According to our literature review, around 31 publications related to diterpenoid dimers were found before 2000 , and this number has increased to 88 in January 2016. However, up to now, no systematical review was carried out on this particular group of diterpenoids. The present review describes the biosynthesis, occurrence and structures of diterpenoid dimers identified up to date, summarizes their bioactivities, gives examples of total synthesis, and explores some research perspectives on diterpenoid dimers.

\section{Biosynthesis}

The biosynthesis of diterpenoids has been widely investigated and involves different modes of cyclization of geranylgeranyl diphosphate (GGPP) [12]. To date, four different classes of synthases have been cloned with their functional proteins sequenced, including casbene synthase, ent-copalyl diphosphate synthase, taxadiene synthase, and abietadiene synthase. In contrast, the biosynthesis of diterpenoid dimers, especially the identification and characterization of the key dimerization processes, has been seldom studied. There are different ways in which diterpenoid dimers can be linked, including a rotatable or atropisomeric $\mathrm{C}-\mathrm{C}$ bond, an ether $\mathrm{C}-\mathrm{O}-\mathrm{C}$ linkage, an ester bond, or a ring formed through homo- or hetero-Diels-Alder reaction. The incorporation of a malonic acid unit to form a diester linkage is observed in the diterpenoid dimers from the families Calceolariaceae and Asteraceae. Most of diterpenoid dimers arise as a result of a Diels-Alder condensation of two monomeric moieties. Yue and colleagues [7] proposed that aphadilactones A-D were formed from two molecules of nemoralisin-type diterpenoid through enzyme-catalyzed Diels-Alder reaction. Later, the total synthesis of these compounds using Diels-Alder cyclization further supported this hypothesis [13]. Until now some progresses have been achieved in the identification of natural Diels-Alderase [14]. Ichihara and colleagues $[15,16]$ isolated and purified an enzyme from Alternaria solani that catalyzes the $[4+2]$ cycloaddition of prosolanapyrone III to the exo adduct solanapyrone A and endo adduct solanapyrone D. This enzyme was the first Diels-Alderase reported. In 2000 , a study carried out by Vederas's group [17] identified a lovastatin nonaketide synthase, which catalyzes intramolecular Diels-Alder endo closure of $(E, E, E)-(R)$-6-methyl-dodecatri2,8,10-enoic acid $N$-acetylcysteamine thioester to a bicyclic system. In a later study, Tanaka's group [18] reported for the first time the $1.70 \AA$ resolution crystal structure of a natural Diels-Alderase, fungal macrophomate synthase, in complex with pyruvate. The authors also determined the active site of the enzyme as large and hydrophobic, with amino acid residues that can form hydrogen-bonds to the substrate 2-pyrone. Additionally, several artificial Diels-Alderases have been generated to catalyze different reactions [19-21]. However, to the best of our knowledge, no
Diels-Alderase catalyzing the formation of diterpenoid dimers has been characterized.

Another common dimerization way in the diterpenoid dimers is through a C-C linkage. Some studies [22,23] propose that this kind of linage is formed through Michael addition or aldol condensation. The formation of an ether bond and a dioxane ring is believed to occur through hemiacetal and acetal reactions. Despite many plausible biosynthetic pathways have been proposed, the nature and extent of enzymes involvement in the formation of diterpenoid dimers remain unclear. There has been no direct observation of enzymatic dimerization of the monomer units. The biosynthesis of diterpenoid dimers is worth further investigation as this promising progress has just started.

\section{Occurrence \\ $\nabla$}

Diterpenoid dimers are rare in nature, and they have been discovered in eighteen families of higher plants, fungi, liverworts and a gorgonian so far. The majority of diterpenoid dimers have been reported from higher plants including the families Acanthaceae (Andrographis), Annonaceae (Annona and Xylopia), Asteraceae (Baccharis), Calceolariaceae (Calceolaria), Chrysobalanaceae (Parinari) Cupressaceae (Calocedrus, Chamaecyparis, Cryptomeria, Cunninghamia, Juniperus, and Taiwania), Euphorbiaceae (Croton, Euphorbia, and Neoboutonia), Fabaceae (Caesalpinia, Cylicodiscus, and Erythrophleum), Lamiaceae (Ballota, Clerodendrum, Isodon, Plectranthus, Premna, Salvia, and Teucrium), Liliaceae (Fritillaria), Meliaceae (Aphanamixis), Rhizophoraceae (Ceriop), Taxaceae (Taxus and Torreya), Velloziaceae (Vellozia), and Zingiberaceae (Alpinia). They are widely distributed throughout the plants from roots, barks, stems, bulbs, leaves, seeds to fruits ( Table 1). Some diterpenoid dimers were found in fungi [Psathyrellaceae (Coprinus)], liverworts [Scapaniaceae (Scapania)] and a gorgonian [Gorgoniidae (Antillogorgia)].

\section{Diterpenoid Dimers from Plants $\nabla$}

\section{Family Acanthaceae}

As part of a search for cell differentiation inducers on mouse myeloid leukemia (M1), the aerial parts of Andrographis paniculata were chemically investigated and four labdanoid dimers, namely bisandrograpolides A-D (1-4) ( Fig. 1), were isolated [24]. All these compounds were deduced to be dimers linked via a $\mathrm{C}-\mathrm{C}$ single bond between $\mathrm{C}-12$ and $\mathrm{C}-15^{\prime}$ of andrographolide derivatives but the respective configurations at $\mathrm{C}-12$ and $\mathrm{C}-15^{\prime}$ of these compounds remained undetermined. Bisandrograpolides A-C showed potent phagocytic and growth-inhibitory activities against M1 cells, while bisandrograpolide D showed no induction of phagocytosis, but exhibited growth-inhibitory effects.

\section{Family Annonaceae}

Thirteen diterpenoid dimers have been isolated from plants of the family Annonaceae but only from the genera Xylopia and Annona (๑ Fig. 2).

Acutifloric acid (5) was isolated from the stem barks of $X$. acutiflora [25], and was identified as a dimer resulting from a DielsAlder condensation between 15-oxo-kaur-16-en-19-oic and labda-8(17),13,15-trien-19-oic. Phytochemical studies of the green fruits of $X$. amazonica and stem barks and leaves of $X$. frutescens resulted in the identification of amazonins $B$ and $A(6,10)$ and 
Table 1 Naturally occurring diterpenoid dimers ${ }^{\mathrm{a}}$.

\begin{tabular}{|c|c|c|c|c|c|}
\hline No. & Name & $\begin{array}{l}\text { Molecular } \\
\text { formula }\end{array}$ & Source & Part & Ref. \\
\hline \multicolumn{6}{|c|}{ Plants } \\
\hline \multicolumn{6}{|c|}{ Acanthaceae } \\
\hline 1 & bisandrograpolide A & $\mathrm{C}_{40} \mathrm{H}_{56} \mathrm{O}_{8}$ & Andrographis paniculata & aerial parts & [24] \\
\hline 2 & bisandrograpolide B & $\mathrm{C}_{40} \mathrm{H}_{56} \mathrm{O}_{8}$ & Andrographis paniculata & aerial parts & [24] \\
\hline 3 & bisandrograpolide $\mathrm{C}$ & $\mathrm{C}_{40} \mathrm{H}_{56} \mathrm{O}_{8}$ & Andrographis paniculata & aerial parts & [24] \\
\hline 4 & bisandrograpolide D & $\mathrm{C}_{41} \mathrm{H}_{60} \mathrm{O}_{9}$ & Andrographis paniculata & aerial parts & [24] \\
\hline \multicolumn{6}{|c|}{ Annonaceae } \\
\hline 5 & acutifloric acid & $\mathrm{C}_{40} \mathrm{H}_{60} \mathrm{O}_{3}$ & Xylopia acutiflora & stem barks & [25] \\
\hline 6 & amazonin B & $\mathrm{C}_{41} \mathrm{H}_{60} \mathrm{O}_{5}$ & Xylopia amazonica & fruits & [26] \\
\hline 7 & frutoic acid & $\mathrm{C}_{40} \mathrm{H}_{60} \mathrm{O}_{4}$ & Xylopia frutescens & stem barks & [27] \\
\hline 8 & emarginatine $D$ & $\mathrm{C}_{42} \mathrm{H}_{62} \mathrm{O}_{5}$ & Xylopia emarginata & stem barks & [26] \\
\hline 9 & emarginatine $A$ & $\mathrm{C}_{42} \mathrm{H}_{62} \mathrm{O}_{5}$ & Xylopia emarginata & branches & [28] \\
\hline 10 & amazonin A & $\mathrm{C}_{41} \mathrm{H}_{60} \mathrm{O}_{5}$ & Xylopia amazonica & fruits & [26] \\
\hline 11 & emarginatine $C$ & $\mathrm{C}_{42} \mathrm{H}_{62} \mathrm{O}_{5}$ & Xylopia emarginata & stem barks & [26] \\
\hline 12 & emarginatine B & $\mathrm{C}_{42} \mathrm{H}_{62} \mathrm{O}_{5}$ & Xylopia emarginata & branches & [28] \\
\hline 13 & ent-methylisoozate dimer & $\mathrm{C}_{42} \mathrm{H}_{64} \mathrm{O}_{4}$ & Xylopia aromatic & stem barks & [29] \\
\hline 14 & ent-13'-nor-13'-oxomethylisoozate dimer & $\mathrm{C}_{41} \mathrm{H}_{62} \mathrm{O}_{5}$ & Xylopia aromatic & stem barks & [29] \\
\hline 15 & ent-13-epoximethylisoozate dimer & $\mathrm{C}_{42} \mathrm{H}_{64} \mathrm{O}_{5}$ & Xylopia aromatic & stem barks & [29] \\
\hline 16 & annonebinide $\mathrm{A}$ & $\mathrm{C}_{40} \mathrm{H}_{64} \mathrm{O}_{3}$ & Annona glabra & stem barks & [30] \\
\hline 17 & annoglabayin & $\mathrm{C}_{38} \mathrm{H}_{62}$ & Annona glabra & fruits & [31] \\
\hline \multicolumn{6}{|c|}{ Asteraceae } \\
\hline 18 & bacchalejin 1 & $\mathrm{C}_{43} \mathrm{H}_{60} \mathrm{O}_{6}$ & Baccharis lejia & aerial parts & [32] \\
\hline 19 & bacchalejin 2 & $\mathrm{C}_{43} \mathrm{H}_{60} \mathrm{O}_{7}$ & Baccharis lejia & aerial parts & [32] \\
\hline 20 & bacchalejin 3 & $\mathrm{C}_{45} \mathrm{H}_{62} \mathrm{O}_{8}$ & Baccharis lejia & aerial parts & [32] \\
\hline 21 & bacchalejin 4 & $\mathrm{C}_{47} \mathrm{H}_{64} \mathrm{O}_{10}$ & Baccharis lejia & aerial parts & [32] \\
\hline \multicolumn{6}{|c|}{ Calceolariaceae } \\
\hline 22 & foliosate & $\mathrm{C}_{43} \mathrm{H}_{64} \mathrm{O}_{4}$ & Calceolaria foliosa & aerial parts & [33] \\
\hline 23 & glandulosate & $\mathrm{C}_{43} \mathrm{H}_{64} \mathrm{O}_{4}$ & Calceolaria glandulosa & aerial parts & [34] \\
\hline 24 & lepidate & $\mathrm{C}_{43} \mathrm{H}_{66} \mathrm{O}_{5}$ & Calceolaria lepida & aerial parts & [35] \\
\hline 25 & polifosate & $\mathrm{C}_{43} \mathrm{H}_{64} \mathrm{O}_{4}$ & Calceolaria polifolia & aerial parts & [36] \\
\hline 26 & petiolate & $\mathrm{C}_{43} \mathrm{H}_{64} \mathrm{O}_{4}$ & Calceolaria petioalaris & aerial parts & [37] \\
\hline 27 & bis-[ent-9-epi-labda-8(17),(12Z),14-trien-19-yl] malonate & $\mathrm{C}_{43} \mathrm{H}_{64} \mathrm{O}_{4}$ & Calceolaria densifolia & aerial parts & [38] \\
\hline \multicolumn{6}{|c|}{ Chrysobalanaceae } \\
\hline 28 & $\begin{array}{l}\text { 15-oxozoapatlin- } 13 \alpha \text {-yl- } 10^{\prime} \alpha, 16^{\prime} \alpha \text {-dihydroxy-9' } \alpha \text {-methyl-20'- } \\
\text { nor-kauran-19'-oic acid } y \text {-lactone- } 17^{\prime} \text {-aote }\end{array}$ & $\mathrm{C}_{40} \mathrm{H}_{52} \mathrm{O}_{8}$ & Parinari campestris & leaves & [39] \\
\hline \multicolumn{6}{|c|}{ Cupressaceae } \\
\hline 29 & $\begin{array}{l}\text { 6-(abieta- } 6^{\prime}, 8^{\prime}, 11^{\prime}, 13^{\prime} \text {-tetraenyl-12'-oxy)-7-methoxyabieta- } \\
8,11,13 \text {-trien-12-ol }\end{array}$ & $\mathrm{C}_{41} \mathrm{H}_{58} \mathrm{O}_{3}$ & Chamaecyparis obtusa & barks & [40] \\
\hline 30 & sugikurojin B & $\mathrm{C}_{41} \mathrm{H}_{58} \mathrm{O}_{3}$ & Cryptomeria japonica & heartwood & [41] \\
\hline 31 & formosadimer $\mathrm{A}$ & $\mathrm{C}_{41} \mathrm{H}_{58} \mathrm{O}_{3}$ & Calocedrus macrolepis & barks & [42] \\
\hline 32 & formosadimer B & $\mathrm{C}_{46} \mathrm{H}_{68} \mathrm{O}_{4}$ & Calocedrus macrolepis & barks & [42] \\
\hline 33 & formosadimer $\mathrm{C}$ & $\mathrm{C}_{48} \mathrm{H}_{70} \mathrm{O}_{5}$ & Calocedrus macrolepis & barks & [42] \\
\hline 34 & calocedimer C & $\mathrm{C}_{40} \mathrm{H}_{56} \mathrm{O}_{3}$ & Calocedrus macrolepis & barks & [43] \\
\hline 35 & calocedimer D & $\mathrm{C}_{44} \mathrm{H}_{60} \mathrm{O}_{5}$ & Calocedrus macrolepis & barks & [43] \\
\hline 36 & formosaninol & $\mathrm{C}_{40} \mathrm{H}_{56} \mathrm{O}_{4}$ & Juniperus formosana & heartwood & [44] \\
\hline 37 & formosanin & $\mathrm{C}_{42} \mathrm{H}_{60} \mathrm{O}_{4}$ & Juniperus formosana & heartwood & [44] \\
\hline 38 & sugikurojin C & $\mathrm{C}_{40} \mathrm{H}_{56} \mathrm{O}_{4}$ & Cryptomeria japonica & heartwood & [41] \\
\hline 39 & obtusanol A & $\mathrm{C}_{40} \mathrm{H}_{56} \mathrm{O}_{4}$ & Chamaecyparis obtusa & heartwood & [45] \\
\hline 40 & obtusanol B & $\mathrm{C}_{40} \mathrm{H}_{54} \mathrm{O}_{5}$ & Chamaecyparis obtusa & heartwood & [45] \\
\hline 41 & bicunningine $\mathrm{A}$ & $\mathrm{C}_{40} \mathrm{H}_{50} \mathrm{O}_{4}$ & Cunninghamia lanceolata & barks & [46] \\
\hline 42 & bicunningine B & $\mathrm{C}_{40} \mathrm{H}_{52} \mathrm{O}_{4}$ & Cunninghamia lanceolata & barks & [46] \\
\hline 43 & taiwaniadduct B & $\mathrm{C}_{40} \mathrm{H}_{56} \mathrm{O}_{6}$ & Taiwania crypomerioides & leaves & [47] \\
\hline 44 & taiwaniadduct $C$ & $\mathrm{C}_{40} \mathrm{H}_{56} \mathrm{O}_{6}$ & Taiwania crypomerioides & leaves & [47] \\
\hline 45 & taiwaniadduct $\mathrm{D}$ & $\mathrm{C}_{40} \mathrm{H}_{56} \mathrm{O}_{6}$ & Taiwania crypomerioides & leaves & [47] \\
\hline 46 & taiwaniadduct $\mathrm{E}$ & $\mathrm{C}_{40} \mathrm{H}_{56} \mathrm{O}_{6}$ & Taiwania crypomerioides & leaves & [47] \\
\hline 47 & taiwaniadduct $F$ & $\mathrm{C}_{40} \mathrm{H}_{56} \mathrm{O}_{6}$ & Taiwania crypomerioides & leaves & [48] \\
\hline 48 & taiwaniadduct $G$ & $\mathrm{C}_{40} \mathrm{H}_{56} \mathrm{O}_{7}$ & Taiwania crypomerioides & leaves & [48] \\
\hline 49 & taiwaniadduct $\mathrm{H}$ & $\mathrm{C}_{39} \mathrm{H}_{56} \mathrm{O}_{6}$ & Taiwania crypomerioides & leaves & [48] \\
\hline 50 & taiwaniadduct I & $\mathrm{C}_{39} \mathrm{H}_{54} \mathrm{O}_{6}$ & Taiwania crypomerioides & leaves & [48] \\
\hline
\end{tabular}


Table 1 Continued

\begin{tabular}{|c|c|c|c|c|c|}
\hline No. & Name & $\begin{array}{l}\text { Molecular } \\
\text { formula }\end{array}$ & Source & Part & Ref. \\
\hline \multicolumn{6}{|c|}{ Euphorbiaceae } \\
\hline 51 & crotoeurin A & $\mathrm{C}_{38} \mathrm{H}_{36} \mathrm{O}_{10}$ & Croton euryphyllus & twigs and leaves & [49] \\
\hline 52 & crotonkinensin C & $\mathrm{C}_{40} \mathrm{H}_{62} \mathrm{O}_{8}$ & Croton tonkinensis & leaves & [50] \\
\hline 53 & crotonkinensin D & $\mathrm{C}_{44} \mathrm{H}_{66} \mathrm{O}_{10}$ & Croton tonkinensis & leaves & [50] \\
\hline 54 & yuexiandajisu D & $\mathrm{C}_{38} \mathrm{H}_{48} \mathrm{O}_{4}$ & Euphorbia ebracteolata & roots & [51] \\
\hline 55 & langduin C & $\mathrm{C}_{40} \mathrm{H}_{50} \mathrm{O}_{10}$ & Euphorbia fischeriana & roots & [52] \\
\hline 56 & bisyinshanic acid A & $\mathrm{C}_{40} \mathrm{H}_{56} \mathrm{O}_{6}$ & Euphorbia yinshanica & roots & [53] \\
\hline 57 & bisyinshanic acid B & $\mathrm{C}_{40} \mathrm{H}_{58} \mathrm{O}_{5}$ & Euphorbia yinshanica & roots & [53] \\
\hline 58 & neoboutomannin & $\mathrm{C}_{32} \mathrm{H}_{26} \mathrm{O}_{6}$ & Neoboutonia mannii & barks & [54] \\
\hline \multicolumn{6}{|c|}{ Fabaceae } \\
\hline 59 & cyclodione & $\mathrm{C}_{40} \mathrm{H}_{56} \mathrm{O}_{4}$ & Cylicodiscus gabunensis & barks & [55] \\
\hline 60 & erythrophlesin A & $\mathrm{C}_{41} \mathrm{H}_{58} \mathrm{O}_{10}$ & Erythrophleum succirubrum & leaves & [56] \\
\hline 61 & erythrophlesin B & $\mathrm{C}_{43} \mathrm{H}_{60} \mathrm{O}_{12}$ & Erythrophleum succirubrum & leaves & [56] \\
\hline 62 & erythrophlesin C & $\mathrm{C}_{43} \mathrm{H}_{63} \mathrm{NO}_{10}$ & Erythrophleum succirubrum & leaves & [56] \\
\hline 63 & erythrophlesin D & $\mathrm{C}_{45} \mathrm{H}_{65} \mathrm{NO}_{12}$ & Erythrophleum succirubrum & leaves & [56] \\
\hline 64 & erythrophlesin E & $\mathrm{C}_{44} \mathrm{H}_{63} \mathrm{NO}_{12}$ & Erythrophleum fordii & leaves & [57] \\
\hline 65 & erythrophlesin F & $\mathrm{C}_{42} \mathrm{H}_{61} \mathrm{NO}_{10}$ & Erythrophleum fordii & leaves & [57] \\
\hline 66 & erythrophlesin G & $\mathrm{C}_{44} \mathrm{H}_{63} \mathrm{NO}_{12}$ & Erythrophleum fordii & leaves & [57] \\
\hline 67 & erythrophlesin $\mathrm{H}$ & $\mathrm{C}_{45} \mathrm{H}_{65} \mathrm{NO}_{10}$ & Erythrophleum fordii & barks & [58] \\
\hline 68 & erythrophlesin I & $\mathrm{C}_{45} \mathrm{H}_{65} \mathrm{NO}_{11}$ & Erythrophleum fordii & barks & [58] \\
\hline 69 & caesanine D & $\mathrm{C}_{42} \mathrm{H}_{55} \mathrm{NO}_{7}$ & Caesalpinia sappan & seeds & [11] \\
\hline \multicolumn{6}{|c|}{ Lamiaceae } \\
\hline 70 & persianone & $\mathrm{C}_{40} \mathrm{H}_{56} \mathrm{O}_{6}$ & Ballota aucheri & aerial parts & [60] \\
\hline 71 & inermes $\mathrm{A}$ & $\mathrm{C}_{52} \mathrm{H}_{74} \mathrm{O}_{19}$ & Clerodendrum inerme & leaves & [61] \\
\hline 72 & inermes B & $\mathrm{C}_{53} \mathrm{H}_{76} \mathrm{O}_{20}$ & Clerodendrum inerme & leaves & [61] \\
\hline 73 & trichotomone & $\mathrm{C}_{40} \mathrm{H}_{48} \mathrm{O}_{9}$ & Clerodendrum trichotomum & roots & [10] \\
\hline 74 & maoecrystal M & $\mathrm{C}_{48} \mathrm{H}_{64} \mathrm{O}_{16}$ & Isodon eriocalyx & leaves & [62] \\
\hline 75 & bistenuifolin L & $\mathrm{C}_{52} \mathrm{H}_{68} \mathrm{O}_{18}$ & Isodon tenuifolius & aerial parts & [64] \\
\hline 76 & bistenuifolin M & $\mathrm{C}_{50} \mathrm{H}_{66} \mathrm{O}_{16}$ & Isodon tenuifolius & aerial parts & [64] \\
\hline 77 & bisjaponin A & $\mathrm{C}_{40} \mathrm{H}_{52} \mathrm{O}_{12}$ & Isodon japonicus & aerial parts & [65] \\
\hline 78 & bisjaponin B & $\mathrm{C}_{40} \mathrm{H}_{54} \mathrm{O}_{12}$ & Isodon japonicus & aerial parts & [65] \\
\hline 79 & lushanrubescensin J & $\mathrm{C}_{40} \mathrm{H}_{52} \mathrm{O}_{12}$ & Isodon rubescens & leaves & [66] \\
\hline 80 & bisrubescensin $C$ & $\mathrm{C}_{40} \mathrm{H}_{56} \mathrm{O}_{12}$ & Isodon rubescens & leaves & [67] \\
\hline 81 & biexcisusin B & $\mathrm{C}_{48} \mathrm{H}_{68} \mathrm{O}_{14}$ & Isodon excisus & aerial parts & [68] \\
\hline 82 & biexcisusin C & $\mathrm{C}_{48} \mathrm{H}_{68} \mathrm{O}_{16}$ & Isodon excisus & aerial parts & [68] \\
\hline 83 & biexcisusin D & $\mathrm{C}_{48} \mathrm{H}_{66} \mathrm{O}_{16}$ & Isodon excisus & aerial parts & [68] \\
\hline 84 & biexcisusin $\mathrm{E}$ & $\mathrm{C}_{48} \mathrm{H}_{66} \mathrm{O}_{16}$ & Isodon excisus & aerial parts & [68] \\
\hline 85 & bistenuifolin A & $\mathrm{C}_{52} \mathrm{H}_{68} \mathrm{O}_{18}$ & Isodon tenuifolius & aerial parts & [64] \\
\hline 86 & bistenuifolin B & $\mathrm{C}_{52} \mathrm{H}_{68} \mathrm{O}_{18}$ & Isodon tenuifolius & aerial parts & [64] \\
\hline 87 & bistenuifolin C & $\mathrm{C}_{48} \mathrm{H}_{64} \mathrm{O}_{16}$ & Isodon tenuifolius & aerial parts & [64] \\
\hline 88 & bistenuifolin $\mathrm{D}$ & $\mathrm{C}_{50} \mathrm{H}_{66} \mathrm{O}_{16}$ & Isodon tenuifolius & aerial parts & [64] \\
\hline 89 & bistenuifolin $\mathrm{E}$ & $\mathrm{C}_{48} \mathrm{H}_{62} \mathrm{O}_{15}$ & Isodon tenuifolius & aerial parts & [64] \\
\hline 90 & bistenuifolin F & $\mathrm{C}_{48} \mathrm{H}_{68} \mathrm{O}_{16}$ & Isodon tenuifolius & aerial parts & [64] \\
\hline 91 & xindongnin $M$ & $\mathrm{C}_{48} \mathrm{H}_{70} \mathrm{O}_{15}$ & Isodon rubescens & leaves & [69] \\
\hline 92 & xindongnin $\mathrm{N}$ & $\mathrm{C}_{48} \mathrm{H}_{68} \mathrm{O}_{15}$ & Isodon rubescens & leaves & [69] \\
\hline 93 & xindongnin $\mathrm{O}$ & $\mathrm{C}_{48} \mathrm{H}_{68} \mathrm{O}_{15}$ & Isodon rubescens & leaves & [69] \\
\hline 94 & bisrubescensin B & $\mathrm{C}_{40} \mathrm{H}_{58} \mathrm{O}_{13}$ & Isodon rubescens & leaves & [67] \\
\hline 95 & biexcisusin A & $\mathrm{C}_{48} \mathrm{H}_{70} \mathrm{O}_{16}$ & Isodon excisus & aerial parts & [68] \\
\hline 96 & bispseurata F & $\mathrm{C}_{44} \mathrm{H}_{60} \mathrm{O}_{14}$ & Isodon pharicus & aerial parts & [23] \\
\hline 97 & bistenuifolin G & $\mathrm{C}_{48} \mathrm{H}_{66} \mathrm{O}_{17}$ & Isodon tenuifolius & aerial parts & [64] \\
\hline 98 & bistenuifolin $\mathrm{H}$ & $\mathrm{C}_{49} \mathrm{H}_{68} \mathrm{O}_{17}$ & Isodon tenuifolius & aerial parts & [64] \\
\hline 99 & bistenuifolin I & $\mathrm{C}_{49} \mathrm{H}_{68} \mathrm{O}_{17}$ & Isodon tenuifolius & aerial parts & [64] \\
\hline 100 & bistenuifolin J & $\mathrm{C}_{45} \mathrm{H}_{64} \mathrm{O}_{15}$ & Isodon tenuifolius & aerial parts & [64] \\
\hline 101 & bistenuifolin K & $\mathrm{C}_{47} \mathrm{H}_{66} \mathrm{O}_{16}$ & Isodon tenuifolius & aerial parts & [64] \\
\hline 102 & bisrubescensin $\mathrm{A}$ & $\mathrm{C}_{43} \mathrm{H}_{60} \mathrm{O}_{13}$ & Isodon rubescens & leaves & [67] \\
\hline 103 & rubescensin M & $\mathrm{C}_{40} \mathrm{H}_{58} \mathrm{O}_{9}$ & Isodon rubescens & leaves & [70] \\
\hline 104 & hebeiabinin $\mathrm{E}$ & $\mathrm{C}_{40} \mathrm{H}_{60} \mathrm{O}_{11}$ & Isodon rubescens & leaves & [71] \\
\hline 105 & hebeiabinin F & $\mathrm{C}_{40} \mathrm{H}_{56} \mathrm{O}_{9}$ & Isodon rubescens & leaves & [71] \\
\hline 106 & hispidanin A & $\mathrm{C}_{42} \mathrm{H}_{56} \mathrm{O}_{6}$ & Isodon hispida & rhizomes & [72] \\
\hline 107 & hispidanin B & $\mathrm{C}_{42} \mathrm{H}_{56} \mathrm{O}_{6}$ & Isodon hispida & rhizomes & [72] \\
\hline 108 & hispidanin C & $\mathrm{C}_{42} \mathrm{H}_{56} \mathrm{O}_{7}$ & Isodon hispida & rhizomes & [72] \\
\hline 109 & hispidanin D & $\mathrm{C}_{42} \mathrm{H}_{56} \mathrm{O}_{7}$ & Isodon hispida & rhizomes & [72] \\
\hline 110 & grandidone A & $\mathrm{C}_{40} \mathrm{H}_{48} \mathrm{O}_{9}$ & Plectranthus grandidentatus & whole plants & [73] \\
\hline
\end{tabular}


Table 1 Continued

\begin{tabular}{|c|c|c|c|c|c|}
\hline No. & Name & $\begin{array}{l}\text { Molecular } \\
\text { formula }\end{array}$ & Source & Part & Ref. \\
\hline 111 & premnalatifolin A & $\mathrm{C}_{40} \mathrm{H}_{50} \mathrm{O}_{6}$ & Premna latifolia & stem barks & [74] \\
\hline 112 & obtusinone D & $\mathrm{C}_{40} \mathrm{H}_{52} \mathrm{O}_{6}$ & Premna obtusifolia & roots & [75] \\
\hline 113 & obtusinone E & $\mathrm{C}_{40} \mathrm{H}_{52} \mathrm{O}_{6}$ & Premna obtusifolia & roots & [75] \\
\hline 114 & hongencaotone & $\mathrm{C}_{40} \mathrm{H}_{50} \mathrm{O}_{5}$ & Salvia prionitis & roots & [76] \\
\hline 115 & bisprioterone A & $\mathrm{C}_{40} \mathrm{H}_{48} \mathrm{O}_{4}$ & Salvia prionitis & roots & [77] \\
\hline 116 & bisprioterone B & $\mathrm{C}_{39} \mathrm{H}_{46} \mathrm{O}_{5}$ & Salvia prionitis & roots & [77] \\
\hline 117 & bisprioterone C & $\mathrm{C}_{38} \mathrm{H}_{42} \mathrm{O}_{6}$ & Salvia prionitis & roots & [77] \\
\hline 118 & rosmanoyl carnosate & $\mathrm{C}_{40} \mathrm{H}_{48} \mathrm{O}_{7}$ & Salvia canariensis & flowers & [78] \\
\hline 119 & salviwardin A & $\mathrm{C}_{40} \mathrm{H}_{54} \mathrm{O}_{4}$ & Salvia wardii & roots & [79] \\
\hline 120 & salviwardin B & $\mathrm{C}_{40} \mathrm{H}_{52} \mathrm{O}_{4}$ & Salvia wardii & roots & [79] \\
\hline 121 & salvialeriafone & $\mathrm{C}_{39} \mathrm{H}_{48} \mathrm{O}_{7}$ & Salvia leriaefolia & whole plants & [80] \\
\hline 122 & salvialeriicone & $\mathrm{C}_{40} \mathrm{H}_{50} \mathrm{O}_{6}$ & Salvia leriaefolia & whole plants & [83] \\
\hline 123 & broussonetone $\mathrm{A}$ & $\mathrm{C}_{40} \mathrm{H}_{60} \mathrm{O}_{4}$ & Salvia broussonetii & roots & [84] \\
\hline 124 & broussonetone B & $\mathrm{C}_{40} \mathrm{H}_{60} \mathrm{O}_{4}$ & Salvia broussonetii & roots & [84] \\
\hline 125 & epirosmanol ester of 12 -O-methyl carnosic acid & $\mathrm{C}_{41} \mathrm{H}_{54} \mathrm{O}_{8}$ & Salvia officinalis & $\begin{array}{l}\text { stems and } \\
\text { leaves }\end{array}$ & [85] \\
\hline 126 & - & $\mathrm{C}_{40} \mathrm{H}_{50} \mathrm{O}_{7}$ & Salvia wagneriana & aerial parts & [86] \\
\hline 127 & - & $\mathrm{C}_{40} \mathrm{H}_{42} \mathrm{O}_{9}$ & Salvia wagneriana & aerial parts & [86] \\
\hline 128 & biteuvisone A & $\mathrm{C}_{40} \mathrm{H}_{52} \mathrm{O}_{8}$ & Teucrium viscidum & whole plants & [87] \\
\hline 129 & biteuvisone B & $\mathrm{C}_{40} \mathrm{H}_{52} \mathrm{O}_{8}$ & Teucrium viscidum & whole plants & [87] \\
\hline \multicolumn{6}{|c|}{ Liliaceae } \\
\hline 130 & fritillebin A & $\mathrm{C}_{42} \mathrm{H}_{66} \mathrm{O}_{5}$ & Fritillaria ebeiensis & bulbs & [88] \\
\hline 131 & fritillebin B & $\mathrm{C}_{44} \mathrm{H}_{68} \mathrm{O}_{7}$ & Fritillaria ebeiensis & bulbs & [88] \\
\hline 132 & fritillebin C & $\mathrm{C}_{40} \mathrm{H}_{64} \mathrm{O}_{3}$ & Fritillaria ebeiensis & bulbs & [89] \\
\hline 133 & fritillebin D & $\mathrm{C}_{40} \mathrm{H}_{64} \mathrm{O}_{3}$ & Fritillaria ebeiensis & bulbs & [89] \\
\hline 134 & fritillebinide $A$ & $\mathrm{C}_{40} \mathrm{H}_{64} \mathrm{O}_{2}$ & Fritillaria ebeiensis & bulbs & [22] \\
\hline 135 & fritillebinide B & $\mathrm{C}_{42} \mathrm{H}_{66} \mathrm{O}_{4}$ & Fritillaria ebeiensis & bulbs & [90] \\
\hline 136 & fritillebinide C & $\mathrm{C}_{42} \mathrm{H}_{66} \mathrm{O}_{4}$ & Fritillaria ebeiensis & bulbs & [91] \\
\hline 137 & fritillebinide D & $\mathrm{C}_{44} \mathrm{H}_{68} \mathrm{O}_{6}$ & Fritillaria ebeiensis & bulbs & [92] \\
\hline 138 & fritillebinide $\mathrm{E}$ & $\mathrm{C}_{44} \mathrm{H}_{68} \mathrm{O}_{6}$ & Fritillaria ebeiensis & bulbs & [92] \\
\hline \multicolumn{6}{|c|}{ Meliaceae } \\
\hline 139 & aphadilactone $\mathrm{A}$ & $\mathrm{C}_{40} \mathrm{H}_{52} \mathrm{O}_{8}$ & Aphanamixis grandifolia & leaves & [7] \\
\hline 140 & aphadilactone B & $\mathrm{C}_{40} \mathrm{H}_{52} \mathrm{O}_{8}$ & Aphanamixis grandifolia & leaves & [7] \\
\hline 141 & aphadilactone C & $\mathrm{C}_{40} \mathrm{H}_{52} \mathrm{O}_{8}$ & Aphanamixis grandifolia & leaves & [7] \\
\hline 142 & aphadilactone D & $\mathrm{C}_{40} \mathrm{H}_{52} \mathrm{O}_{8}$ & Aphanamixis grandifolia & leaves & [7] \\
\hline 143 & aphanamene C & $\mathrm{C}_{40} \mathrm{H}_{54} \mathrm{O}_{8}$ & Aphanamixis grandifolia & root barks & [8] \\
\hline 144 & aphanamene D & $\mathrm{C}_{40} \mathrm{H}_{54} \mathrm{O}_{8}$ & Aphanamixis grandifolia & root barks & [8] \\
\hline 145 & aphanamene $\mathrm{E}$ & $\mathrm{C}_{40} \mathrm{H}_{54} \mathrm{O}_{8}$ & Aphanamixis grandifolia & root barks & [8] \\
\hline 146 & aphanamene F & $\mathrm{C}_{40} \mathrm{H}_{54} \mathrm{O}_{8}$ & Aphanamixis grandifolia & root barks & [8] \\
\hline 147 & aphanamene K & $\mathrm{C}_{40} \mathrm{H}_{52} \mathrm{O}_{8}$ & Aphanamixis grandifolia & root barks & [8] \\
\hline 148 & aphanamene L & $\mathrm{C}_{40} \mathrm{H}_{52} \mathrm{O}_{8}$ & Aphanamixis grandifolia & root barks & [8] \\
\hline 149 & aphanamene M & $\mathrm{C}_{40} \mathrm{H}_{52} \mathrm{O}_{8}$ & Aphanamixis grandifolia & root barks & [8] \\
\hline 150 & aphanamene $\mathrm{N}$ & $\mathrm{C}_{40} \mathrm{H}_{52} \mathrm{O}_{8}$ & Aphanamixis grandifolia & root barks & [8] \\
\hline 151 & aphanamene G & $\mathrm{C}_{40} \mathrm{H}_{54} \mathrm{O}_{8}$ & Aphanamixis grandifolia & root barks & [8] \\
\hline 152 & aphanamene $\mathrm{H}$ & $\mathrm{C}_{40} \mathrm{H}_{54} \mathrm{O}_{8}$ & Aphanamixis grandifolia & root barks & [8] \\
\hline 153 & aphanamene I & $\mathrm{C}_{40} \mathrm{H}_{54} \mathrm{O}_{8}$ & Aphanamixis grandifolia & root barks & [8] \\
\hline 154 & aphanamene J & $\mathrm{C}_{40} \mathrm{H}_{54} \mathrm{O}_{8}$ & Aphanamixis grandifolia & root barks & [8] \\
\hline 155 & aphanamene $\mathrm{O}$ & $\mathrm{C}_{40} \mathrm{H}_{52} \mathrm{O}_{8}$ & Aphanamixis grandifolia & root barks & [8] \\
\hline 156 & aphanamene P & $\mathrm{C}_{40} \mathrm{H}_{52} \mathrm{O}_{8}$ & Aphanamixis grandifolia & root barks & [8] \\
\hline 157 & aphanamene B & $\mathrm{C}_{40} \mathrm{H}_{52} \mathrm{O}_{8}$ & Aphanamixis grandifolia & root barks & [95] \\
\hline 158 & aphanamene $\mathrm{A}$ & $\mathrm{C}_{40} \mathrm{H}_{54} \mathrm{O}_{7}$ & Aphanamixis grandifolia & root barks & [95] \\
\hline 159 & aphadilactone I & $\mathrm{C}_{40} \mathrm{H}_{54} \mathrm{O}_{7}$ & Aphanamixis grandifolia & leaves & [9] \\
\hline 160 & aphadilactone E & $\mathrm{C}_{40} \mathrm{H}_{52} \mathrm{O}_{8}$ & Aphanamixis grandifolia & leaves & [9] \\
\hline 161 & aphadilactone F & $\mathrm{C}_{40} \mathrm{H}_{52} \mathrm{O}_{8}$ & Aphanamixis grandifolia & leaves & [9] \\
\hline 162 & aphadilactone G & $\mathrm{C}_{40} \mathrm{H}_{52} \mathrm{O}_{8}$ & Aphanamixis grandifolia & leaves & [9] \\
\hline \multicolumn{6}{|c|}{ Rhizophoraceae } \\
\hline 163 & tagalsin I & $\mathrm{C}_{40} \mathrm{H}_{60} \mathrm{O}_{2}$ & Ceriop tagal & stems and twigs & [96] \\
\hline 164 & tagalsin J & $\mathrm{C}_{40} \mathrm{H}_{58} \mathrm{O}_{3}$ & Ceriop tagal & stems and twigs & [96] \\
\hline 165 & tagalsin L & $\mathrm{C}_{40} \mathrm{H}_{60} \mathrm{O}_{3}$ & Ceriop tagal & roots & [97] \\
\hline 166 & tagalsin $\mathrm{M}$ & $\mathrm{C}_{40} \mathrm{H}_{58} \mathrm{O}_{2}$ & Ceriop tagal & roots & [97] \\
\hline 167 & tagalsin $\mathrm{N}$ & $\mathrm{C}_{40} \mathrm{H}_{58} \mathrm{O}_{2}$ & Ceriop tagal & roots & [97] \\
\hline 168 & $\begin{array}{l}\text { 8(14)-enyl-pimar-2'(3')-en-4'(18')-en-15'(16')-en-dolabr- } \\
16,15,2^{\prime}, 3^{\prime} \text {-oxoan-16-one }\end{array}$ & $\mathrm{C}_{40} \mathrm{H}_{58} \mathrm{O}_{2}$ & Ceriop tagal & roots & $\begin{array}{c}{[98]} \\
\text { cont }\end{array}$ \\
\hline
\end{tabular}


Table 1 Continued

\begin{tabular}{|c|c|c|c|c|c|}
\hline No. & Name & $\begin{array}{l}\text { Molecular } \\
\text { formula }\end{array}$ & Source & Part & Ref. \\
\hline \multicolumn{6}{|c|}{ Taxaceae } \\
\hline 169 & grandione & $\mathrm{C}_{40} \mathrm{H}_{56} \mathrm{O}_{6}$ & Torreya grandis & stems & [99] \\
\hline 170 & diabietane ether & $\mathrm{C}_{41} \mathrm{H}_{60} \mathrm{O}_{5}$ & Taxus cuspidata & needles & [100] \\
\hline \multicolumn{6}{|c|}{ Velloziaceae } \\
\hline 171 & bismagdalenic acid & $\mathrm{C}_{40} \mathrm{H}_{60} \mathrm{O}_{4}$ & Vellozia magdalenae & whole plants & [101] \\
\hline \multicolumn{6}{|c|}{ Zingiberaceae } \\
\hline 172 & pahangensin C & $\mathrm{C}_{40} \mathrm{H}_{58} \mathrm{O}_{6}$ & Alpinia pahangensis & rhizomes & [102] \\
\hline \multicolumn{6}{|c|}{ Fungi, liverworts and gorgonian } \\
\hline \multicolumn{6}{|c|}{ Psathyrellaceae } \\
\hline 173 & radianspene $\mathrm{M}$ & $\mathrm{C}_{40} \mathrm{H}_{50} \mathrm{O}_{6}$ & Coprinus radians & fruiting body & [103] \\
\hline \multicolumn{6}{|c|}{ Scapaniaceae } \\
\hline 174 & scapaundulin A & $\mathrm{C}_{32} \mathrm{H}_{48} \mathrm{O}_{6}$ & Scapania undulata & whole plants & [104] \\
\hline 175 & scapaundulin B & $\mathrm{C}_{40} \mathrm{H}_{64} \mathrm{O}_{6}$ & Scapania undulata & whole plants & [104] \\
\hline \multicolumn{6}{|c|}{ Gorgoniidae } \\
\hline 176 & bisersolanolide & $\mathrm{C}_{40} \mathrm{H}_{48} \mathrm{O}_{10}$ & Pseudopterogorgia bipinnata & whole animals & [105] \\
\hline
\end{tabular}

aThe diterpenoid dimers are grouped according to biological sources. For plants, families and genera are listed in alphabetical order.

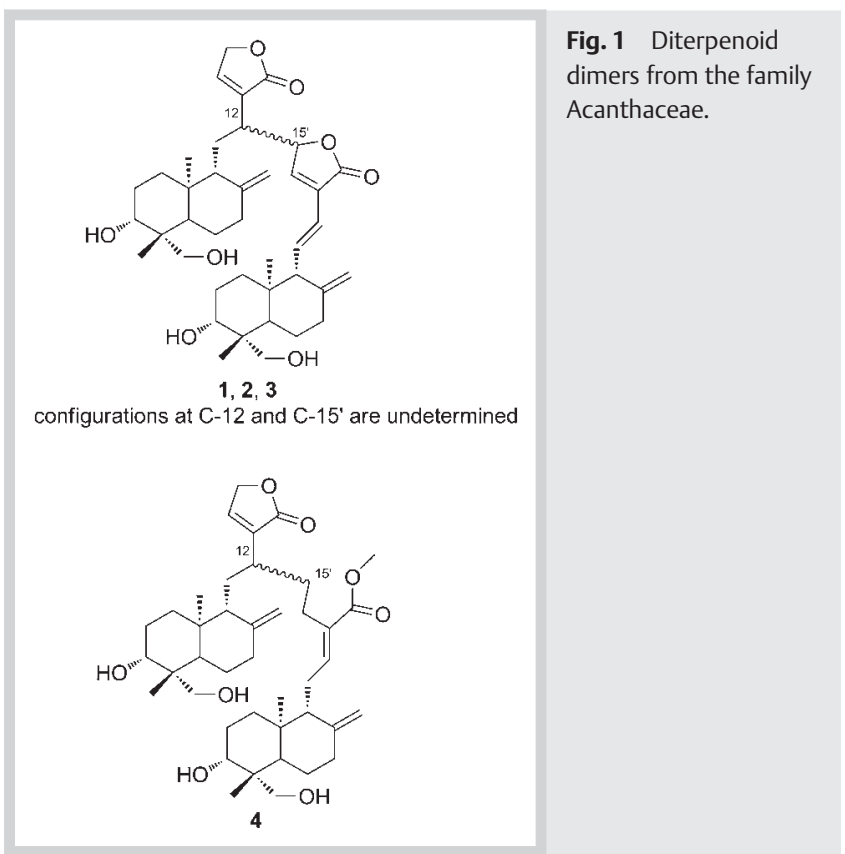

frutoic acid (7), respectively [26,27]. In other studies, emarginatines A-D $(\mathbf{8}, \mathbf{9}, \mathbf{1 1}, \mathbf{1 2})$ were isolated from the branches and stem barks of $X$. emarginata $[26,28]$. These dimers are composed of kauranoid and labdanoid units, and could be considered as taxonomic markers of the genus Xylopia. Three diterpenoid dimers linked through a six-membered ring via a Diels-Alder condensation of two labdanoid units, namely ent-methylisoozate dimer (13), ent-13'-nor-13'-oxomethylisoozate dimer (14) and ent-13epoximethylisoozate dimer (15), were isolated from the stem barks of $X$. aromatica [29]. They were the first labdanoid dimers identified from the family Annonaceae.

Annonebinide A (16) was identified from the stems of A. glabra and determined to be a dimer with two ent-kauranoid units linked via an ester bond between C-17 and C-17' [30]. Annoglabayin (17), a kauranoid dimer, was isolated from A. glabra with its structure determined on the basis of spectroscopic analysis

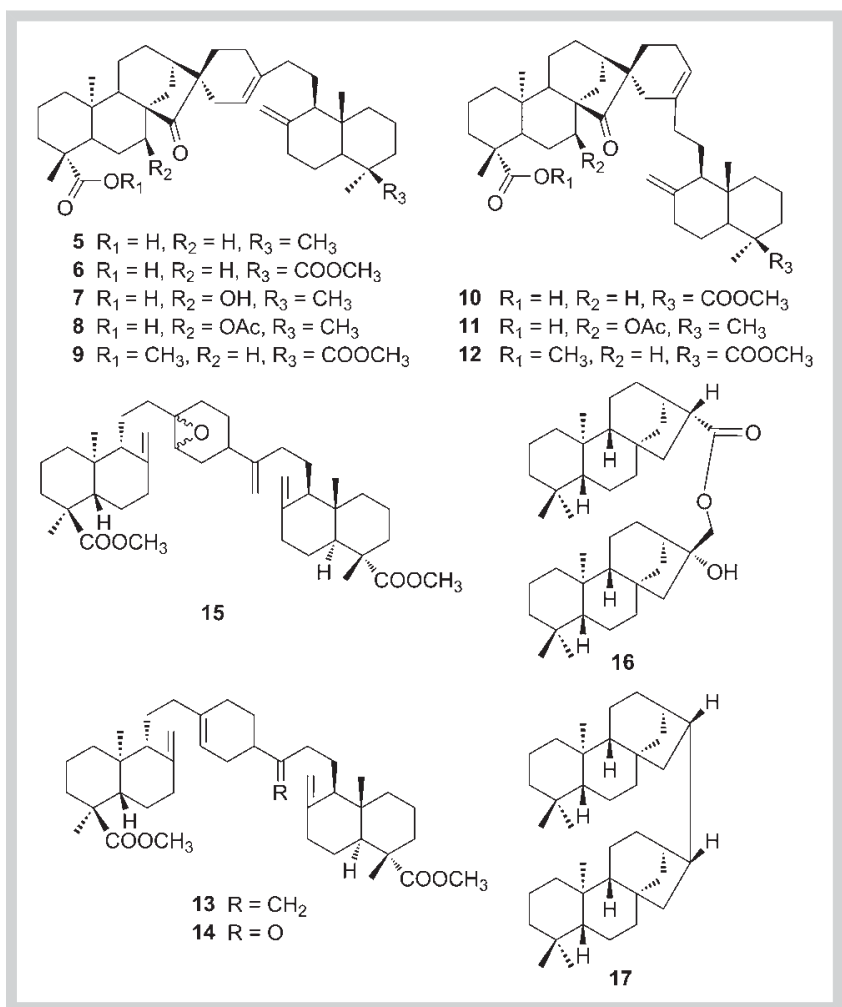

Fig. 2 Diterpenoid dimers from the family Annonaceae.

[31]. Annoglabayin has a unique $\mathrm{C}-\mathrm{C}$ linkage between two norent-kauranoid units.

\section{Family Asteraceae}

Four clerodanoid dimers linked via a C-18 malonate ester, bacchalejins 1-4 (18-21) (O Fig. 3), were reported from the aerial parts of Baccharis lejia [32]. These compounds represent the first and the only examples of diterpenoid dimers from the family Asteraceae. 


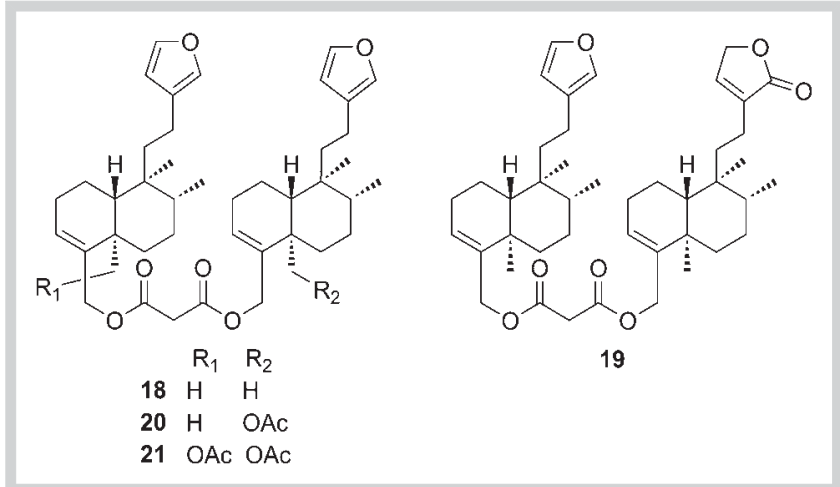

Fig. 3 Diterpenoid dimers from the family Asteraceae.

Family Calceolariaceae

In the family Calceolariaceae, six diterpenoid dimers have been identified, all of which were from the genus Calceolaria (O Fig. 4). They are linked through C-17, C-18 or C-19 by a malonic acid unit. Three dimers composed of two isopimarane-type units, foliosate (22), glandulosate (23), and lepidate (24), were isolated from the aerial parts of $C$. foliosa, C. glandulosa, and $C$. lepida, respectively [33-35]. Additionally, polifosate (25) and petiolate (26) were identified from C. polifolia and C. petioalaris, respectively, which are composed of two pimarane-type units [36, 37]. Interestingly, bis-[ent-9-epi-labda-8(17),(12Z),14-trien-19yl] malonate (27), a dimer composed of two labdane-type units, was also isolated from C. densifolia [38].

\section{Family Chrysobalanaceae}

A kauranoid dimer, 15 -oxozoapatlin-13 $\alpha$-yl-10' $\alpha, 16^{\prime} \alpha$-dihydroxy-9' $\alpha$-methyl-20'-nor-kauran-19'-oic acid $\gamma$-lactone-17'aote (28) ( 0 Fig. 4), was isolated from the leaves of Parinari campestris and identified on the basis of 2D NMR and ESI-MS [39]. It is the only diterpenoid dimer reported from the family Chrysobalanaceae.

\section{Family Cupressaceae}

Plants from the family Cupressaceae are rich in abietane-type diterpenoids [3]. At present, twenty-two diterpenoid dimers have been identified from this family ( $\boldsymbol{O}$ Fig. $\mathbf{5}$ ). Among them, fourteen compounds possess two abietane-type units, and eight others are composed of an abietane-type unit and a labdane-type unit.

A dimer, 6-(abieta-6', $8^{\prime}, 11^{\prime}, 13^{\prime}$-tetraenyl-12'-oxy)-7-methoxyabieta-8,11,13-trien-12-ol (29), was isolated from the stem barks of Chamaecyparis obtusa [40]. It is composed of two abietanoid units linked via an ether bridge between C- 6 and C-12'. In a phytochemical investigation of the black heartwood of Cryptomeria japonica, sugikurojin B (30) was identified as a dimer of 6,7-dihydroxyferruginol and 6,7-dehydroferruginol with a 6-0-12' linkage [41]. In chemical studies of the barks of Calocedrus macrolepis, five abietanoid dimers with the same linkage pattern as sugikurojin B were isolated, including formosadimers A-C (31-33) [42] and calocedimers $C$ and D $(34,35)[43]$. Formosaninol $(36)$ and formosanin (37) were isolated from the heartwood of Juniperus formosana [44]. The structure of formosaninol was deduced to be a dimeric ferruginol with $6-0-7^{\prime}$ and $7-O-6^{\prime}$ linkages on the basis of spectroscopic analysis and chemical evidences. Formosanin was a dimethyl ether of formosaninol. Sugikurojin C (38) was a dimeric ferruginol with the same planar structure as formosa-

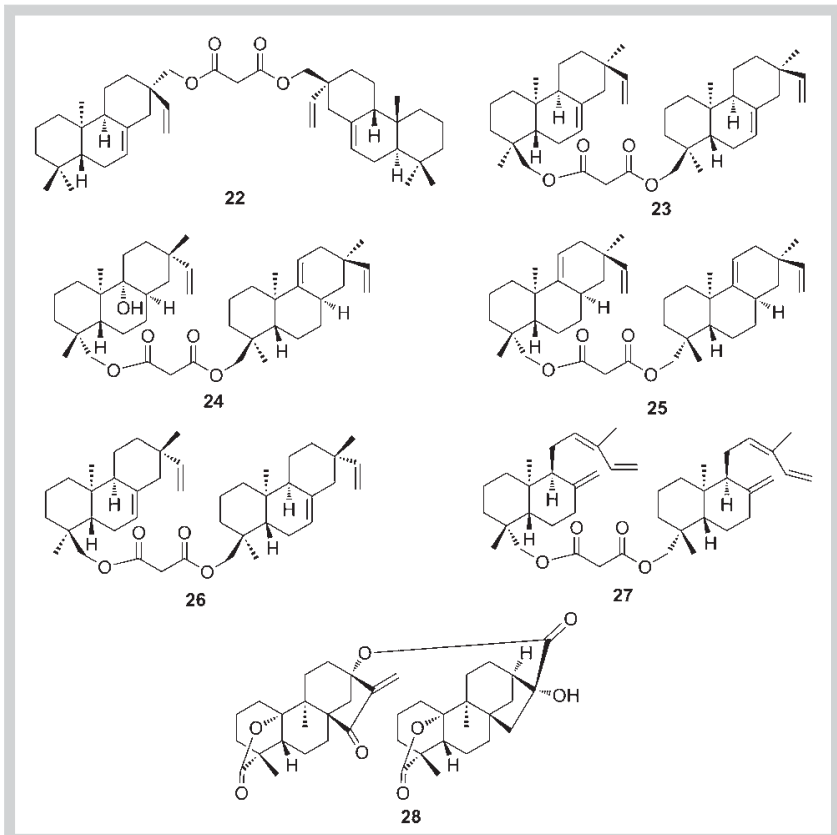

Fig. 4 Diterpenoid dimers from the families Calceolariaceae and Chrysobalanaceae.

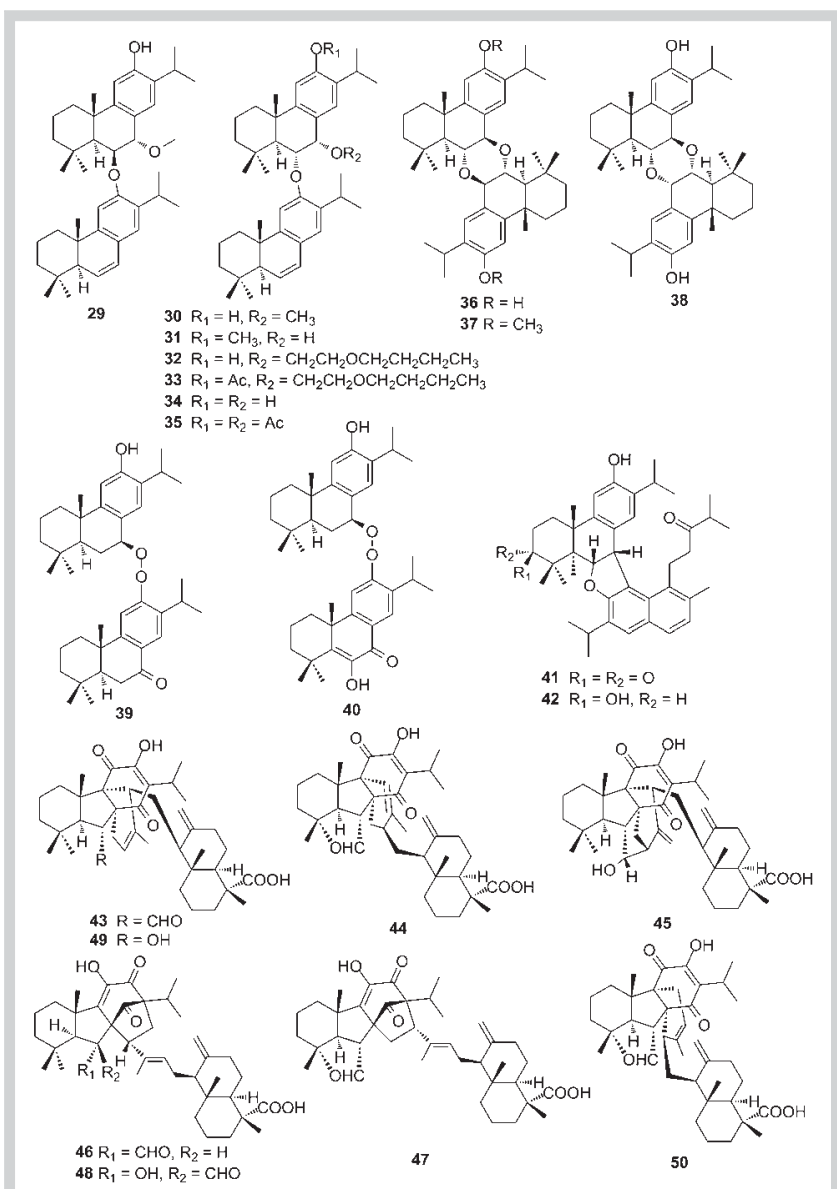

Fig. 5 Diterpenoid dimers from the family Cupressaceae.

ninol, which was isolated from the black heartwood of Cryptomeria japonica [41]. The only difference between the two com- 
pounds is the configuration at C-7'. Two diterpenoid dimers, namely obtusanols $A$ and $B(39,40)$, were isolated from the heartwood of Chamaecyparis obtusa, and characterized by spectroscopic means and chemical degradation [45]. Obtusanols A and $B$ have a rare peroxide bond linking two abietanoid units between C-7 and C-12'. In another study, bicunningines A and B $(41,42)$ were isolated from Cunninghamia lanceolata [46]. Their structures were elucidated by spectroscopic measurements. Their absolute configurations were determined by quantum chemical TDDFT (time-dependent density functional theory) ECD calculations, chemical transformations and Mosher's method. They were the first diterpenoid dimers reported to contain a 2,3-dihydrofuran ring fusing an abietanoid and a 4,5-seco-abietanoid.

Taiwaniadducts B-J (43-50) were isolated from the leaves of Taiwania crypomerioides and identified as dimers composed of an abietanoid unit and a labdanoid unit $[47,48]$. Taiwaniadducts $B$, $\mathrm{C}, \mathrm{H}$ and I were presumably derived from a [4+2] Diels-Alder reaction of the labdane trans-ozic acid and different taiwaniaquinones; while taiwaniadducts $E-G$ appeared to result from the corresponding [5+2] Diels-Alder reaction. Taiwaniadducts B-J are the only naturally occurring heterodimers formed by abietanoid and labdanoid units, and could be considered as taxonomic markers of the species T. crypomerioides. They have attracted strong synthetic interest due to their structural complexity.

\section{Family Euphorbiaceae}

Plants from the family Euphorbiaceae are rich in sesquiterpenoids and diterpenoids. At present, eight diterpenoid dimers have been isolated from this family ( Fig. 6).

In a chemical study of the twigs and leaves of Croton euryphyllus, a nor-clerodanoid dimer, namely crotoeurin A (51), was isolated, which contains a unique cyclobutane ring formed via [2+2] cycloaddition [49]. The structure was elucidated by spectroscopic analysis and the configuration was confirmed by single crystal $\mathrm{X}$-ray diffraction. Crotoeurin A represents the first nor-clerodanoid dimer with a cyclobutane ring and is of particular significance for the biosynthesis of clerodane-type diterpenoids. Crotoeurin A exhibited neurite outgrowth-promoting activity on nerve growth factor-mediated PC12 cells at a concentration of $10 \mu \mathrm{M}$. During a screening program for cytotoxic compounds, two symmetric ent-kauranoid dimers with connectivity at C-17, namely crotonkinensins $C$ and $D(\mathbf{5 2}, \mathbf{5 3})$, were isolated from the leaves of the Vietnamese endemic medicinal plant $C$. tonkinensis [50]. ent-Kauranoid diterpenoids are rarely found from the genus Croton, and these two compounds are the first examples from this genus. Crotonkinensin D showed potent cytotoxic activity against MCF-7, tamoxifen-resistant MCF-7 and adriamycin-resistant MCF-7 breast cancer cell lines, with $\mathrm{IC}_{50}$ values of $9.4 \pm 1.7,2.6 \pm 0.9$, and $18.9 \pm 0.6 \mu \mathrm{M}$, respectively.

In another study, yuexiandajisu D (54), an 18-nor-rosane-type diterpenoid dimer, was isolated from the roots of Euphorbia ebracteolata [51]. It is the first and to date the only example of 18-norrosane-type diterpenoid dimer isolated from the family Euphorbiaceae. Yuexiandajisu D showed weak cytotoxic activity against HCT-8 and Bel-7402 cancer cell lines, with $\mathrm{IC}_{50}$ values of 2.66 and $3.76 \mathrm{mM}$, respectively. Langduin C (55) was isolated from the roots of $E$. fischeriana and its structure was established by spectroscopic data and single crystal X-ray diffraction analysis [52]. Langduin $C$ is a symmetrical diterpenoid dimer with a five-membered $C$ ring instead of the normal six-membered $C$ ring found in the ent-abietane-type diterpenoids. It is the first diterpenoid

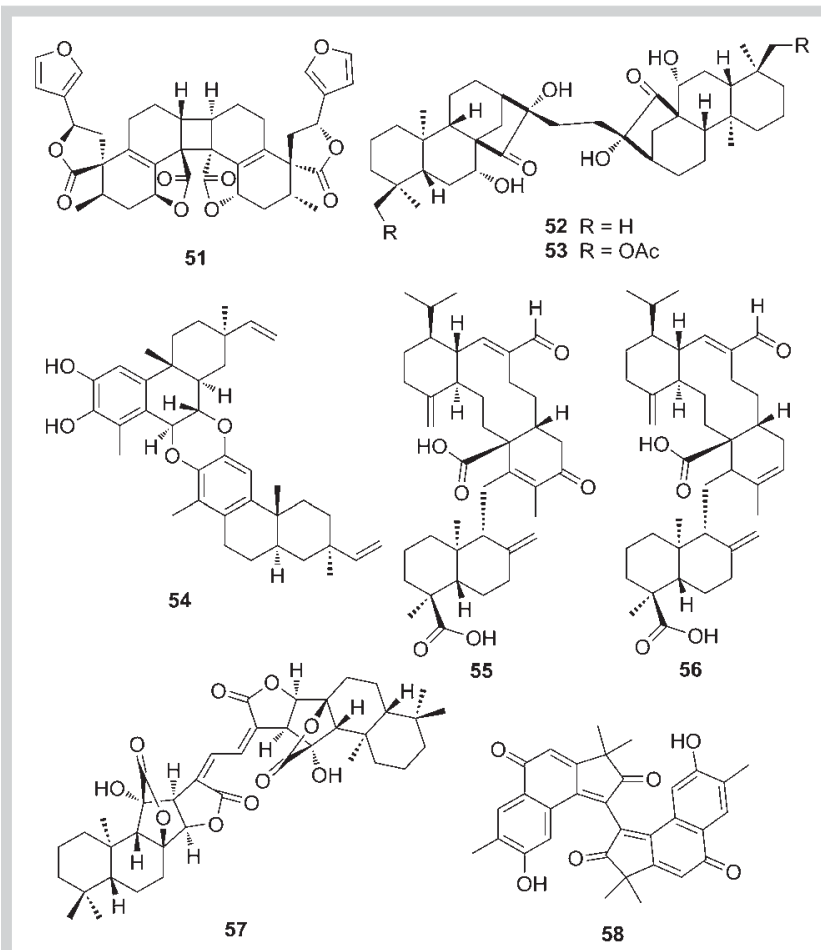

Fig. 6 Diterpenoid dimers from the family Euphorbiaceae.

dimer from the genus Euphobia. This dimer is probably derived from jolkinolide $\mathrm{B}$, a major ent-abietane-type diterpenoid of this plant, by successive oxidative cleavage of ring $C$ and $D$, rearrangement, lactonization, and dimerization. Two diterpenoid dimers with a bismagdalenic acid skeleton, namely bisyinshanic acids $A$ and $\mathrm{B}(\mathbf{5 6}, \mathbf{5 7})$, were isolated from the roots of E. yinshanica [53]. Their structures were elucidated on the basis of spectroscopic evidences.

Neoboutomannin (58), a degraded diterpenoid dimer, was isolated from the stem barks of Neoboutonia mannii [54]. Neoboutomannin was active against Enterococcus faecalis, Staphylococcus aureus, Proteus mirabilis, and three Candida species, C. albicans, C. tropicalis and C. parapsilosis.

\section{Family Fabaceae}

At present, eleven diterpenoid dimers with a cassane-type skeleton have been identified from plants of the family Fabaceae (๑ Fig. 7).

A chemical investigation of the stem barks of Cylicodiscus gabunensis resulted in the identification of the cassanoid dimer cyclodione (59) [55]. Cyclodione was proposed to be formed through a [4+2] Diels-Alder reaction between two cassanoid units.

Nine diterpenoid dimers were isolated from plants of the genus Erythrophleum. They possess an unsymmetrical dimeric structure with two cassanoid units linked through an ester bond at C16 and $C-3^{\prime}$ [56-58]. These compounds could be considered as taxonomic markers of this genus. TRAIL is a promising agent for new anticancer therapy as it can induce apoptosis in a variety of cancer cells but not in normal cells [59]. Bioassay-guided fractionation of the extract of E. succirubrum for TRAIL resistance-overcoming activity led to the isolation of four cassanoid dimers, namely erythrophlesins A-D (60-63) [56]. These four compounds are the first examples of cassanoid dimers linked via an ester 


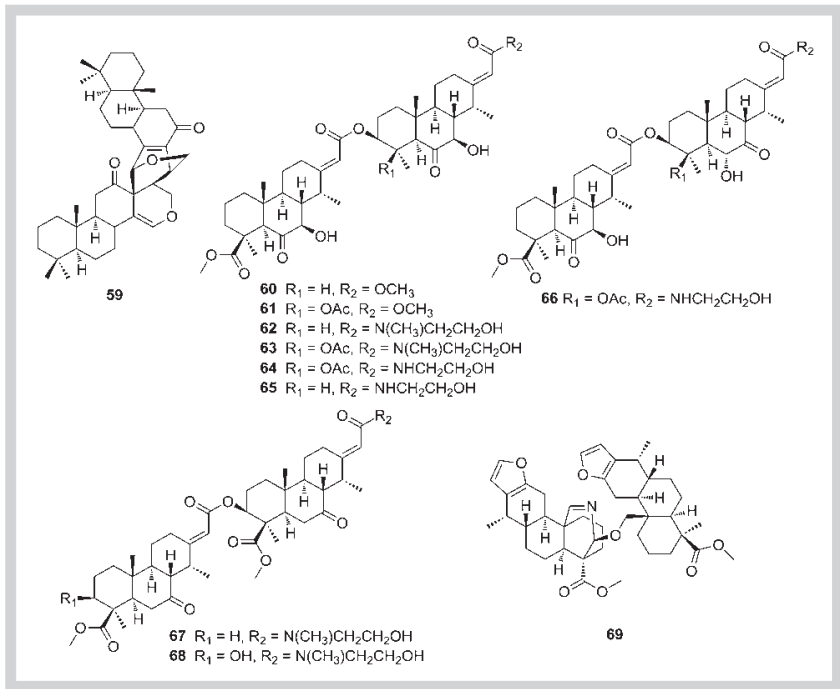

Fig. 7 Diterpenoid dimers from the family Fabaceae.

bond, which are rarely found in nature. Moreover, erythrophlesins $C$ and $D$ possess an amide moiety, which is seldom found in naturally occurring diterpenoids. Erythrophlesins A-C exhibited significant TRAIL resistance-overcoming activity in human gastric adenocarcinoma cells. A detailed phytochemical investigation of the leaves of $E$. fordii resulted in the isolation of three cassanoid dimers, namely erythrophlesins E-G (64-66), all of which were found to contain an amide group [57]. Their structures were determined by extensive 1D and 2D NMR analyses and ESIMS. Cytotoxic activity of these compounds was evaluated against HCT-8, Bel-7402, BGC-823, A549, and A2780 human cancer cell lines in an MTT assay. All three compounds exhibited significant cytotoxic activity $\left(\mathrm{IC}_{50}<10 \mu \mathrm{M}\right)$ against these cells. Cytotoxic activity-guided fractionation of $E$. fordii led to the isolation of two cassanoid amide dimers, namely erythrophlesins $\mathrm{H}$ and I (67, 68) [58]. An MTT assay confirmed that erythrophlesin H had significant cytotoxic effect toward the human prostate cancer PC-3 cell line, with an $\mathrm{IC}_{50}$ value of $12.5 \mu \mathrm{M}$.

In a recent study, a cassanoid dimer, namely caesanine D (69), was isolated from the seeds of Caesalpinia sappan [11]. Caesanine D represents the first example of a cassanoid dimer where the subunits are linked via an ether bond. Interestingly, one of the diterpene units of this compound possesses a cassane-type skeleton with an unusual $\mathrm{N}$ bridge between C-19/C-20. The structure was determined by various spectroscopic methods and ECD calculation.

\section{Family Lamiaceae}

Plants of the family Lamiaceae contributed a significant number of diterpenoid dimers. At present, 60 diterpenoid dimers have been isolated and structurally characterized. Most are homodimers, composed of two diterpenoids units with the same core skeleton. Twenty-nine kaurane-type diterpenoid dimers were reported from the genus Isodon, and could be considered as taxonomic markers of this genus; sixteen abeitane-type diterpenoid dimers were identified from the genera Salvia, Clerodendrum, Plectranthus, and Teucrium; four clerodane-type diterpenoid dimers were found from the genera Salvia and Clerodendrum; three icetexane-type diterpenoid dimers were from the genus Premna; and one labdane-type dimer was from the genus Ballota.

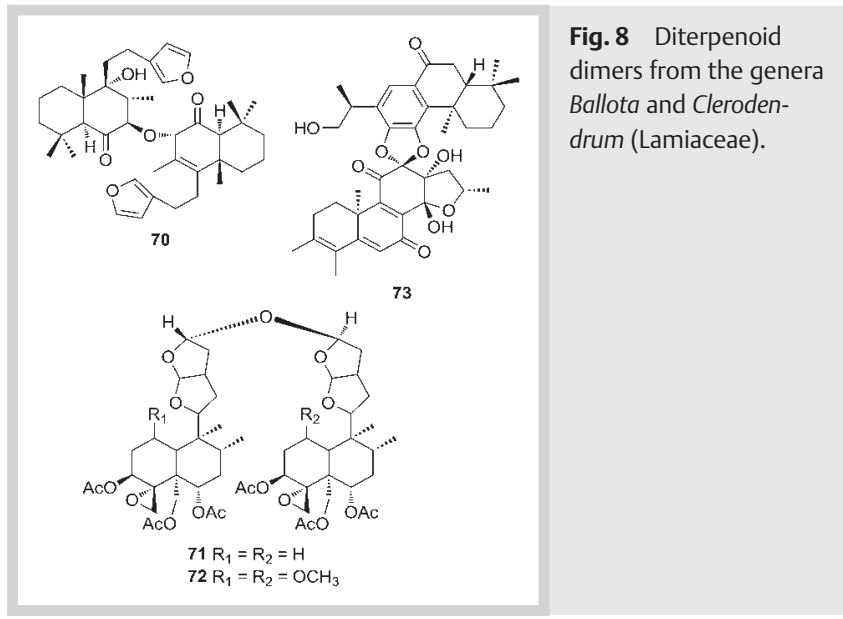

Besides, some are rare heterodimers, consisting of two units belonging to different types of diterpenoids. Four dimers composed of a totarene-type unit and a labdane-type unit, as well as three dimers containing an abietane-type unit and a kaurane-type unit were isolated from the genus Isodon.

Ballota genus. A study on the chemical constituents of $B$. aucheri led to the isolation of persianone (70) ( $\bullet$ Fig. 8), a dimer composed of two labdane-type units linked through an ether bond at C-7 [60]. The structure of persianone was elucidated by high field NMR spectroscopy, including NOE difference experiments, and chemical transformations.

Clerodendrum genus. Two compounds, namely inermes A and B $(\mathbf{7 1}, 72)$ ( Fig. 8), were isolated from C. inerme [61]. On the basis of comprehensive spectroscopic analysis, both compounds were elucidated to contain two clerodane units linked through an ether bridge at $\mathrm{C}-15$. Interestingly, a hexahydrofurofuran ring was found in each clerodane unit. The isolation and structural elucidation of trichotomone (73) ( Fig. 8) was reported from the roots of the medicinal ornamental plant C. trichotomum [10]. This compound is a rare phenolic ketal derivative consisting of a regular abietanoid and a rearranged abietanoid derivative in a 17 $(15 \rightarrow 16), 18(4 \rightarrow 3)$-diabeo-abietane framework. The structure was elucidated by extensive spectroscopic methods. The absolute configuration was defined by comparison of experimental and calculated ECD spectra. Trichotomone exhibited significant in vitro cytotoxicity against several human cancer cell lines (A549, Jurkat, BGC-823, and 293 T WT) with $\mathrm{IC}_{50}$ values ranging from 7.51 to $19.38 \mu \mathrm{M}$.

Isodon genus. Besides lots of diterpenoid monomers, the genus Isodon is also a major source of diterpenoid dimers with a considerable structural diversity. At present, 36 dimers have been isolated from this genus, most of which possess a kaurane-type core skeleton (๑ Fig. 9-11).

Maoecrystal M (74) ( Fig. 9), the first example of naturally occurring ent-kaurane-type dimer, was isolated from I. eriocalyx [62]. By means of ${ }^{1} \mathrm{H}^{-1} \mathrm{H}$ COSY and ROESY, as well as chemical transformation, the structure of maoecrystal $M$ was determined to be a symmetric dimer of an ent-kaurane diterpenoid connected at $16 \mathrm{R}, 16^{\prime} \mathrm{R}$ through a cyclobutane ring. The four-membered ring was proposed to be formed by condensation between the olefinic bond in the $\alpha, \beta$-unsaturated ketone group of the monomer diterpenoid, probably through a $[2+2]$ cycloaddition [63]. In a chemical study of I. tenuifolius, bistenuifolins L and M (75 and 76) ( Fig. 9) were isolated and found to possess the 


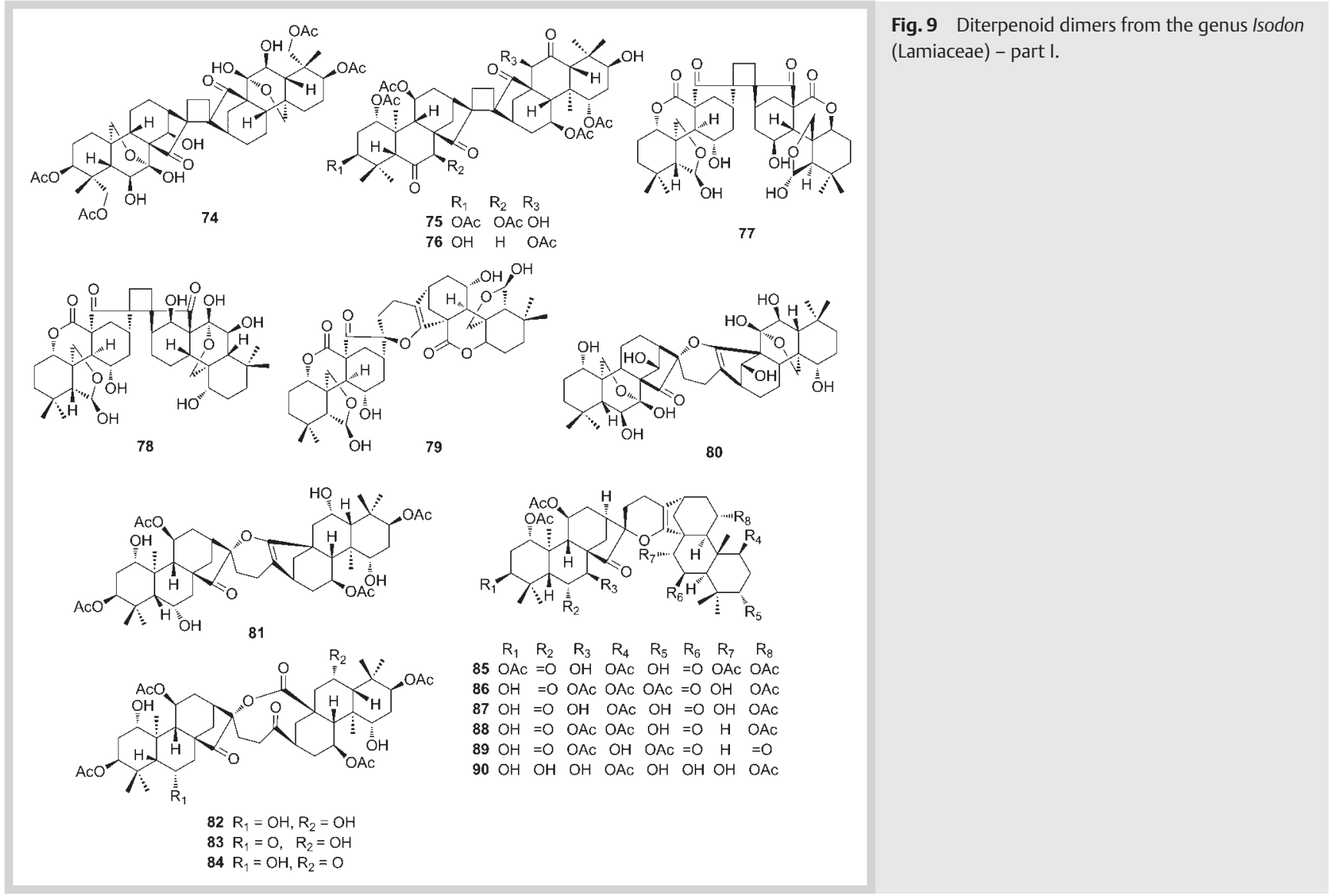

same skeleton as maoecrystal M [64]. In 2008, another two entkaurane-type dimers connected with a four-membered carbon ring, namely bisjaponins A and B (77 and 78) ( Fig. 9), were isolated from the aerial parts of I. japonicus [65]. These two compounds contain a 6,7-seco-6,20-epoxy-ent-kaurane fragment. An asymmetric ent-kauranoid dimer, namely lushanrubescensin J (79) ( Fig. 9), was isolated from I. rubescens var. lushanensis [66]. Its structure was established by spectroscopic evidences and single crystal X-ray diffraction. It is the first ent-kauranoid dimer found to possess a dihydropyran ring resulting from a [4+2] cycloaddition between the $\alpha, \beta$-unsaturated ketone group of one diterpenoid and the olefinic bond of another diterpenoid. Interestingly, this compound contains a 6,7-seco-6,20-epoxyent-kaurane monomer. Lushanrubescensin J exhibited potent inhibitory activity against $\mathrm{K} 562$ cells with an $\mathrm{IC}_{50}$ value of $0.93 \mu \mathrm{g} /$ $\mathrm{mL}$. Bisrubescensin C (80) (๑ Fig. 9), an ent-kauranoid dimer with the same linkage pattern as lushanrubescensin J, was isolated from I. rubescens [67]. Four ent-kauranoid dimers, namely biexcisusins B-E (81-84) (๑ Fig. 9), were reported from I. excisus [68]. Their structures which are closely related to bisrubescensin $C$ were established on the basis of detailed spectroscopic analyses. Biexcisusins C-E possess an unprecedented linkage through a nine-membered lactone ring between two ent-kaurane-type subunits. The lactone ring was proposed to arise through oxidative cleavage of the double bond of the dihydropyran ring in biexcisusin B. In a chemical study of I. tenuifolius, six ent-kauranoid dimers, namely bistenuifolins A-F (85-90) ( $\odot$ Fig. 9), were identified and found to be linked by a dihydropyran ring [64]. The structures of these compounds were established via spectroscopic analysis. The absolute configurations of bistenuifolins A and D were defined by single crystal X-ray diffraction. Bistenuifolin B exhibited significant cytotoxicity against several human cancer cell lines, including HL-60, SMMC-7721, MCF-7, and SW-480, with $\mathrm{IC}_{50}$ values ranging from 4.0 to $9.9 \mu \mathrm{M}$.

Three asymmetric dimers, namely xindongnins M-O (91-93) ( Fig. 10), have been isolated from I. rubescens var. rubescens [69]. They represent the first examples of ent-kauranoid dimers with a rare linkage through a single $\mathrm{C}-\mathrm{C}$ bond between two units. Their structures were characterized by spectroscopic methods including 2D NMR analyses. The relative configuration of xindongnin $\mathrm{M}$ was determined by single crystal X-ray diffraction. ent-Kauranoids isolated from the genus Isodon normally have $\alpha, \beta$-unsaturated ketone groups. The [4+2] cycloaddition between the $\alpha, \beta$-unsaturated ketone of one diterpene unit and the olefinic bond of the second unit might yield a dihydropyran ring. In a further step, hydrolysis and rearrangement at the dihydropyran ring could produce the single $\mathrm{C}-\mathrm{C}$ bond linkage. Two other ent-kauranoid dimers, namely bisrubescensin B (94) and biexcisusin A (95) (๑ Fig. 10), connected with a single C-C bond linkage, were isolated from I. rubescens [67] and I. excisus [68], respectively. The co-occurrence of dimers with a single $\mathrm{C}-\mathrm{C}$ bond linkage (bisrubescensin $B$ and biexcisusin $A$ ) and congeners with a dihydropyran ring (bisrubescensin $C$ and biexcisusin $B$ ) in the same plant further supports the above proposed biosynthetic pathway. A phytochemical investigation of I. pharicus led to the isolation of an asymmetric dimer, namely bispseurata $\mathrm{F}$ (96) ( Fig. 10), which is the first and the only example of ent-kauranoid dimer connected by direct linkage of $\mathrm{C}-17$ with $\mathrm{C}-11^{\prime}$ [23]. A Michael addition reaction is proposed to be the key step in the biosynthesis of bispseurata F. The dimerization of this type of di- 


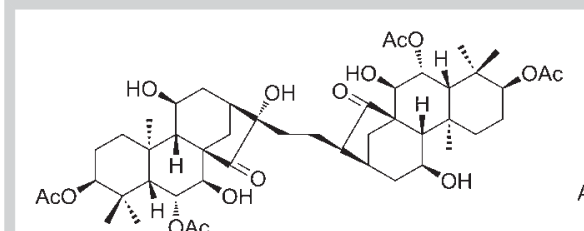

91

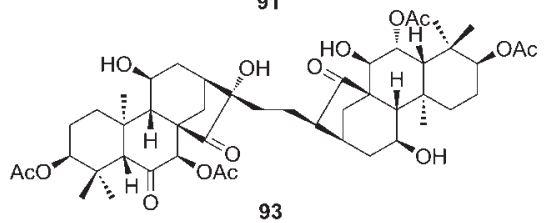

93

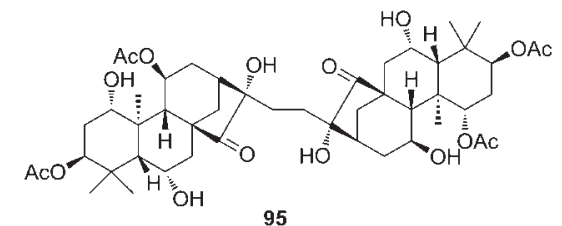

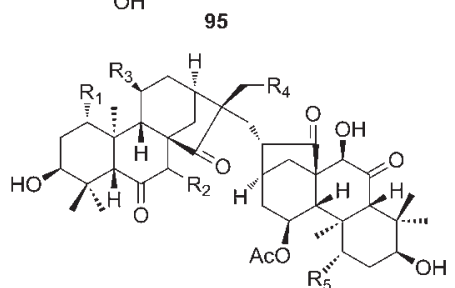

$R_{1} \quad R_{2}$

$\begin{array}{lll}R_{3} & R_{4} & R_{5}\end{array}$

$97 \mathrm{OAC}$ beta-OH OAC OH OAC

98 OAc beta-OH OAc OMe OAc

99 OAc alpha-OH OAc OMe OAc

$100 \mathrm{OH}$ beta-OH OH OMe OAC

$101 \mathrm{OAc}$ beta-OH OAc OMe $\mathrm{OH}$

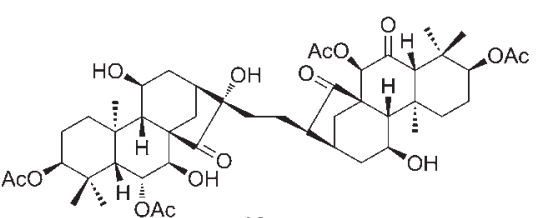

92

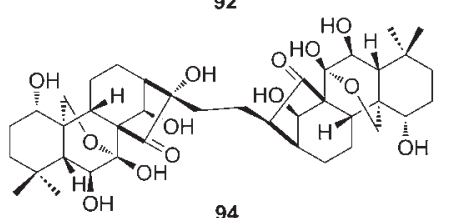

94

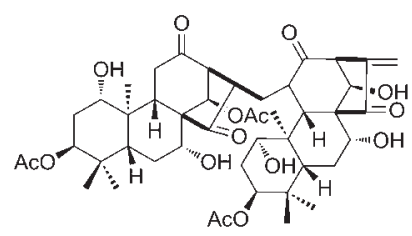

96

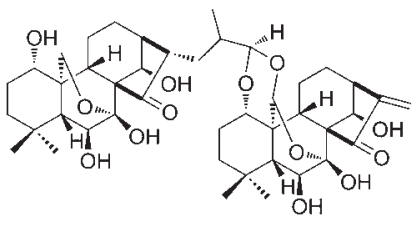

102
Fig. 10 Diterpenoid dimers from the genus Isodon (Lamiaceae) - part II. terpenoid dimers is worth further studies. Five ent-kauranoid dimers linked by a unique $\mathrm{C}-16$ to $\mathrm{C}-17$ ' single bond, namely bistenuifolins G-K (97-101) ( Fig. 10), were identified from I. tenuifolius [64]. Bisrubescensin A (102) (Fig. $\bigcirc 10$ ) is an ent-kauranoid dimer from I. rubescens and contains an unprecedented $C_{23}$ ent-kaurane unit [67].

Rubescensin M (103) (๑ Fig. 11) was isolated from I. rubescens [70]. By detailed spectroscopic analysis, it was deduced to be a dimer linked by an oxygen bridge between $\mathrm{C}-18$ of an abietanoid and C-20' of a kauranoid. Abietane-type diterpenoids are very rare in the genus Isodon, and rubescensin $\mathrm{M}$ is the first heterodimer from this genus. In a chemical study of I. rubescens, hebeiabinins $E$ and $F(104,105)$ ( $\odot$ Fig. 11) were identified with the same linkage pattern as rubescensin M [71]. Hebeiabinin F showed significant inhibitory activity against A549 and HT-29 cells with $\mathrm{IC}_{50}$ values of 0.91 and $1.81 \mu \mathrm{M}$, respectively.

Hispidanins A-D (106-109) ( Fig. 11) are four unprecedented heterodimers formed by the bonding of totarane-type and labdane-type diterpenoids. They were obtained from the rhizomes of I. hispida [72]. Their structures were elucidated by extensive spectroscopic analyses, and the structure of hispidanin A was further confirmed by single crystal X-ray diffraction. Totarane-type diterpenoids are rarely found in nature. Hispidanins A-D are the first and the only naturally occurring heterodimers composed of a labdane-type and a totarane-type diterpenoid. The biosynthetic pathway of hispidanins A-D was proposed to involve an intermolecular Diels-Alder reaction between totarane-type and labdanetype derivatives. Hispidanin B showed significant cytotoxicity against tumor cell lines SGC7901, SMMC7721, and K562, with $\mathrm{IC}_{50}$ values of $10.7,9.8$, and $13.7 \mu \mathrm{M}$, respectively.
Plectranthus genus. An abietanoid dimer linked by a ketal, namely grandidone A (110) ( $\odot$ Fig. 12), was isolated from P. grandidentatus [73]. This compound showed slight antiproliferative activity against five human cancer cell lines MCF-7, NCI-H460, SF-268, TK-10, and UACC-62, with $\mathrm{GI}_{50}$ values of $9.6 \pm 1.8,19.2 \pm 3.1$, $25.8 \pm 4.0,40.9 \pm 3.7$, and $35.7 \pm 1.5 \mu \mathrm{M}$, respectively.

Premna genus. Premnalatifolin A (111) ( Fig. 12), a unique icetexanoid dimer, was isolated from the stem barks of the Indian medicinal plant $P$. latifolia [74]. Its structure and relative configuration were elucidated on the basis of detailed spectroscopic analyses, including HRESIMS and 2D NMR spectra. This compound is composed of two icetexanoid units linked via an ether bridge. The formation of premnalatifolin A was proposed to follow a radical reaction. A phenoxyl radical of one subunit reacted with a phenyl radical of the other subunit to result in the ether bridge. Premnalatifolin A displayed potent cytotoxicity against HT-29 and MCF-7 cell lines with $\mathrm{IC}_{50}$ values of 12.15 and $1.11 \mu \mathrm{g} / \mathrm{mL}$, respectively. In 2013, two icetexanoid dimers, namely obtusinones D and E (112 and 113) ( Fig. 12), were isolated from the roots of $P$. obtusifolia, and were suggested to be formed via a hetero-Diels-Alder type dimerization reaction [75]. Obtusinone D represents the first example of a linearly fused icetexanoid dimer, whereas obtusinone $\mathrm{E}$ is an angularly fused icetexanoid dimer. The structures of obtusinones D and E were elucidated on the basis of 1D and 2D NMR spectroscopic analyses. Icetexanoid dimers could be considered as taxonomic markers of the genus Premna.

Salvia genus. Fourteen diterpenoid dimers have been isolated from the genus Salvia, including twelve abietane-type dimers and two clerodane-type dimers ( Fig. 13). Abietanoid dimers 


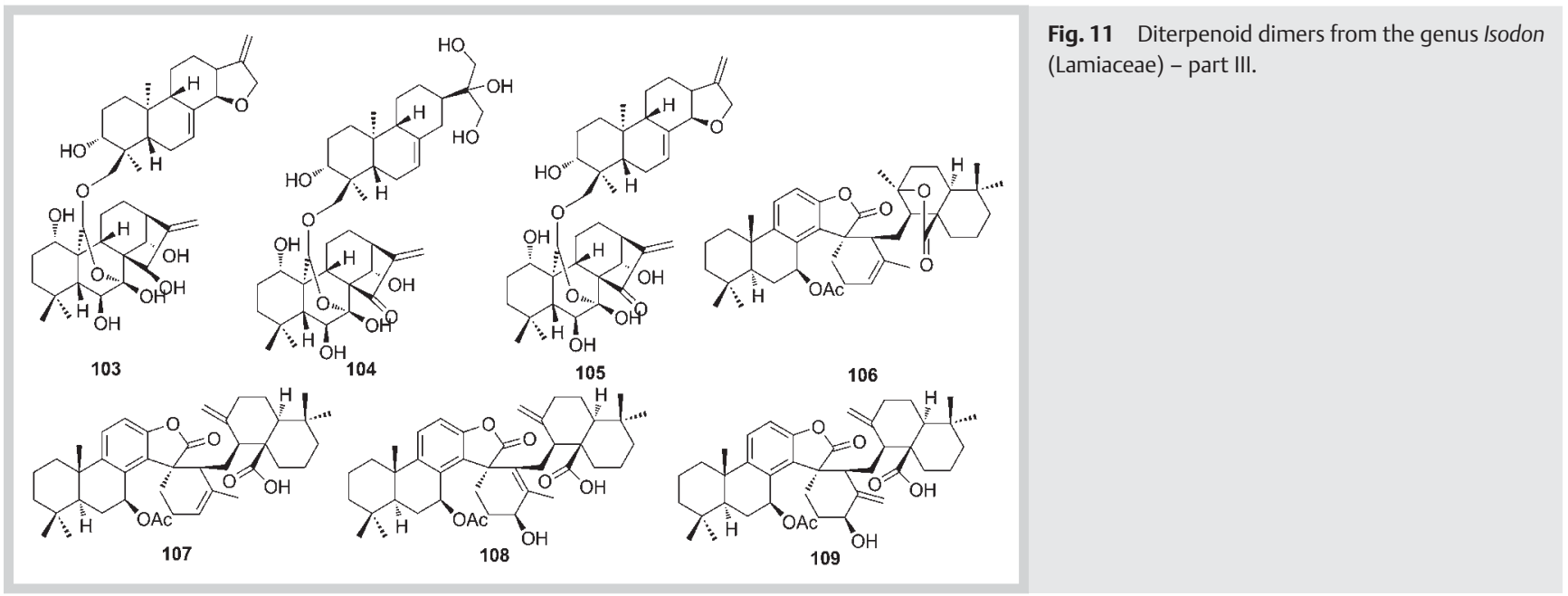

from the genus Salvia are linked via $\mathrm{C}-\mathrm{C}$ single bond, ether bridge, dioxane ring, or ketal moiety.

The abietanoid dimer hongencaotone (114) was isolated from the roots of $S$. prionitis and its structure was determined by spectroscopic data interpretation and X-ray analysis [76]. From the same species, three further abietanoid dimers, namely bisprioterones A-C (115-117), were identified by Zhang and his colleagues [77]. Bisprioterone A possesses two 4,5-seco abietanoid subunits linked via a $\mathrm{C}-\mathrm{C}$ single bond at $\mathrm{C}-14$ and $\mathrm{C}-\mathrm{1}^{\prime}$. In bisprioterone $\mathrm{B}$ the subunits are connected via a $\mathrm{C}-\mathrm{C}$ single bond between $\mathrm{C}-14$ of an abietanoid subunit and C-1' of a 4,5-seco abietanoid subunit. Bisprioterone $\mathrm{C}$ possesses an ether bridge linked between $\mathrm{C}-12$ of an abietanoid subunit and $\mathrm{C}^{-1} \mathbf{1}^{\prime}$ of an 11,12 -seco abietanoid subunit. Their structures were characterized by analysis of 1D and 2D NMR spectroscopic data. The structure of bisprioterone A was further confirmed by single crystal X-ray diffraction. In contrast to their monomers these diterpenoid dimers did not exhibit obvious cytostatic, antiphlogistic, or antibacterial activities. The disappearance of some functional groups during the dimerization process might account for the decrease of the bioactivities. In 1987, rosmanoyl carnosate (118), a dimer composed of two abietanoid units linked via an ether bond between C-7 and C20 , was isolated from the flowers of $S$. canariensis [78]. It was the first ether-linked diterpenoid dimer identified from the genus Salvia. Two other dimers, namely salviwardins A and B (119 and 120), were isolated from the roots of S. wardii [79]. In both compounds, two abietanoid subunits are connected via a dioxane ring. Salvialeriafone (121), a diterpene-norditerpene conjugate, was isolated from $S$. leriaefolia and its structure was determined by spectroscopic data analysis [80]. Salvialeriafone which contains a spiro-dihydrofuran moiety attached to ring $\mathrm{C}$ of the norditerpenoid unit is the first example of norditerpene-diterpene conjugated abietanoid dimer. The probable origin of the spiro-dihydrofuran group is proposed to be through a nucleophilic addition/substitution between the 1,6,12-trihydroxy derivative of sibiriquinone $\mathrm{B}$ [81] and the 6-deoxo analogue of 14-hydroxytaxodion [82]. This compound exhibited antiproliferative activity against HeLa cells with an $\mathrm{IC}_{50}$ value of $10.91 \mu \mathrm{M}$. Salvialeriicone (122), isolated from S. leriifolia, is an abietanoid dimer connected via a dihydropyran ring [83]. The structure was determined using mass spectrometry and NMR spectroscopy. In a chemical study of S. broussonetii, two abietanoid dimers, namely broussonetones A and $B(123,124)$, were isolated [84]. Their structures were deter-

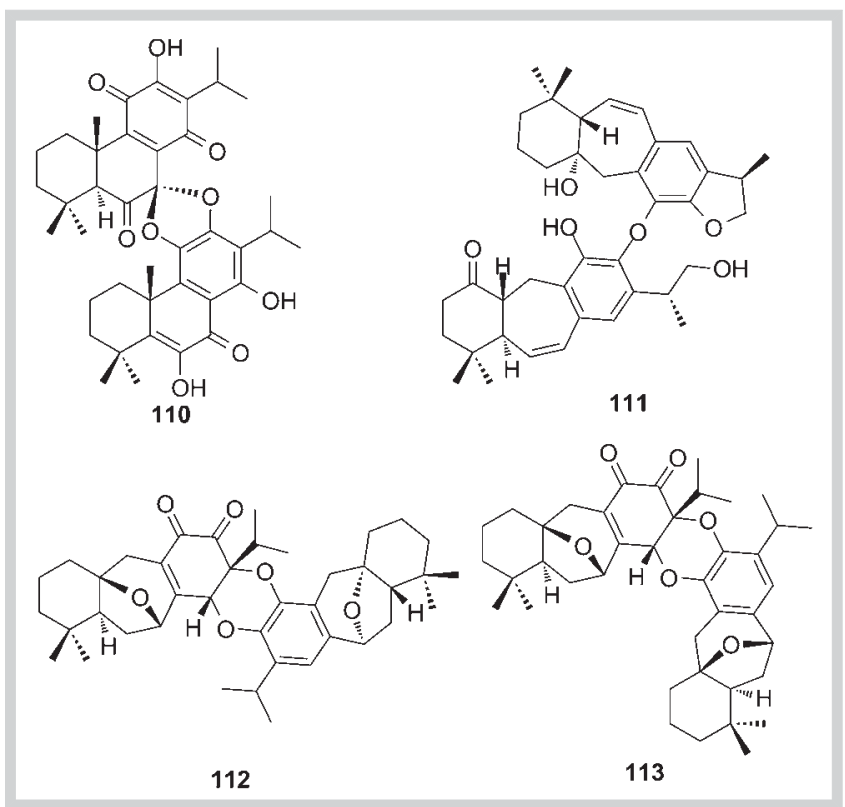

Fig. 12 Diterpenoid dimers from the genera Plectranthus and Premna (Lamiaceae).

mined based on spectroscopic data and confirmed by X-ray analysis. These dimers could be formed by a [4+2] cycloaddition of two molecules of 13 $\beta$-hydroxyabieta-8(14),9(11)-dien-12-one. Broussonetones $A$ and $B$ are the first non-phenolic or quinonic abietanoid dimers to be isolated from natural sources. In a study aimed to the identification of nuclear peroxisome proliferatoractivated receptor (PPAR)- $\gamma$ activators from $S$. officinalis, the epirosmanol ester of 12-O-methyl carnosic acid (125), was identified. This compound contains two abietanoid subunits linked by an ester bond [85]. As the only example of abietanoid dimer resulting from the formation of an ester bond, it was considered as an artefact formed during extraction and isolation. This was further supported by the fact that this compound was not detectable in the crude extract by HPLC analysis.

From the aerial parts of $S$. wagneriana, two clerodanoid dimers (126 and 127) were obtained with their structures established by 1D- and 2D-NMR spectroscopic analyses [86]. They are the on- 


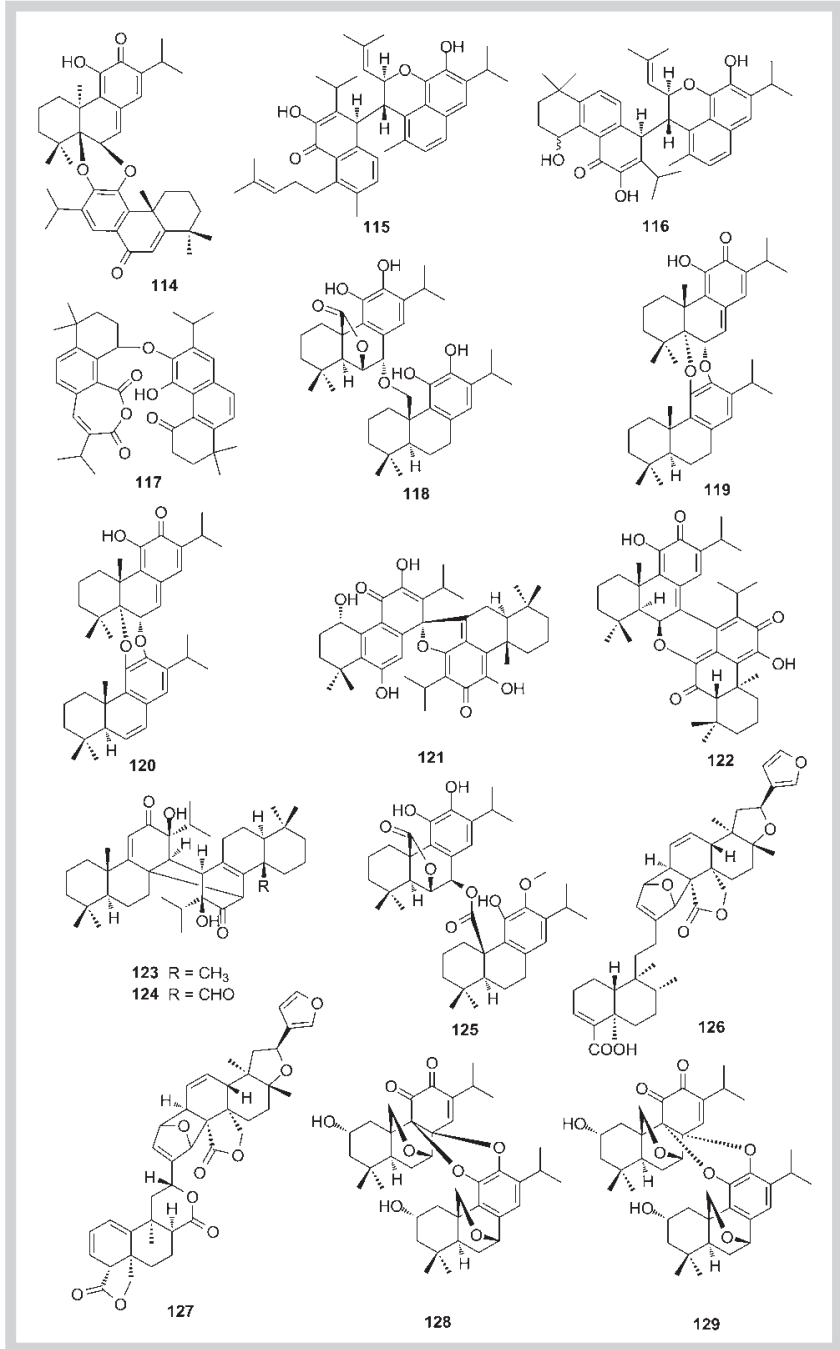

Fig. 13 Diterpenoid dimers from the genera Salvia and Teucrium (Lamiaceae).

ly clerodane-type diterpenoid dimers reported from the genus Salvia.

Teucrium genus. A pair of dimeric abietanoid stereoisomers connected via a dioxane ring, namely biteuvisones A and B (128 and 129) ( Fig. 13), were isolated from T. viscidum [87]. These two compounds are proposed to be formed through a hetero-DielsAlder reaction of the o-quinone of teuvisone.

\section{Family Liliaceae}

Nine diperpenoid dimers were isolated from the bulbs of Fritillaria ebeiensis (Liliaceae). They contain two ent-kauranoid units linked through an ester bond or a dioxolane ring ( $\bullet$ Fig. 14). In 1995, Wu and colleagues [88] found two compounds, namely fritillebins $A$ and $B(130,131)$, which possess an ent-kauranoid dimer skeleton linked via an ester bond between C-17 and C-17'. These compounds are the first diterpenoid dimers identified from the family Liliaceae. Later, the same group [89] reported other two dimers, namely fritillebins $C$ and $D(132,133)$, from the same plant. These two dimers share the same core skeleton as fritillebin A. An acetal diterpenoid dimer with ent-kauranoid skeleton, namely fritillebinide A (134), was isolated from the bulbs of $F$. ebeiensis [22]. The structure of fritillebinide A was elu-

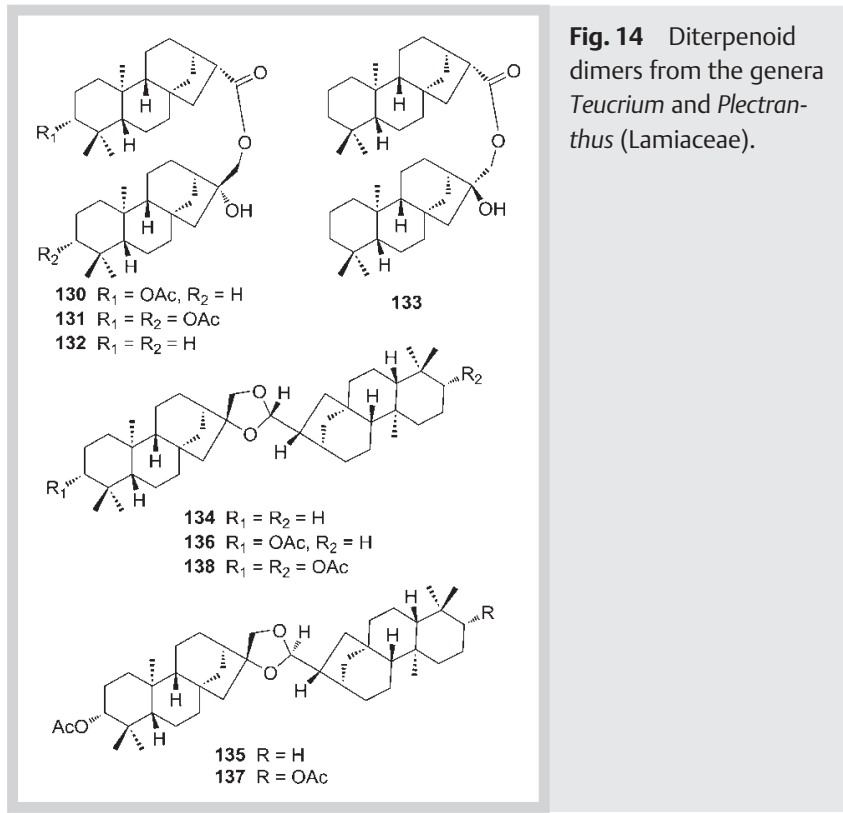

cidated by spectroscopic analysis and chemical synthesis. It represents the first ent-kauranoid dimer possessing a dioxolane ring formed by aldol condensation. In subsequent studies, two pairs of further ent-kauranoid dimers containing a dioxolane ring, namely fritillebinides $B$ and $C(135,136)$ and fritillebinides $D$ and $E(137,138)$, were isolated from the same plant [90-92]. Fritillebinides B and D have a R configuration at C-17' while fritillebinides $\mathrm{C}$ and $\mathrm{E}$ have a $\mathrm{S}$ configuration at this position.

\section{Family Meliaceae}

Diterpenoids are not widely found in plants of the family Meliaceae. In fact, Aphanamixis grandifolia is the only source of diterpenoid dimers in this family, which has contributed 25 congeners in recent years ( $\odot$ Fig. 15). A. grandifolia is an arbor tree mainly distributed in the tropical and subtropical areas of Asia [93]. Its leaves and roots are used as folk medicine in China to treat rheumatism and alleviate pain [94]. As part of a search for new DGAT inhibitors, the ethanolic extract of $A$. grandifolia was found to exhibit significant inhibition against DGAT-1. Bioassay-guided isolation resulted in identification of four diastereoisomers possessing an unprecedented carbon skeleton, namely aphadilactones A-D (139-142) [7]. Their structures and absolute configurations were determined by a combination of spectroscopic data, chemical degradation, partial synthesis, experimental CD spectra and ECD calculations. Aphadilactones A-D were proposed to be formed from two molecules of nemoralisin-type diterpenoid through an enzyme-catalyzed [4+2] cycloaddition reaction, which leads to a cyclohexene ring with a 2,2-dimethylfuran-3 $(2 \mathrm{H})$-one ring and the substituents attached at the para-position [7]. According to further biological evaluation, aphadilactone $C$ is a potent DGAT-1 inhibitor $\left(\mathrm{IC}_{50}=0.46 \pm 0.09 \mu \mathrm{M}\right)$ with marginal activity against DGAT-2 $\left(\mathrm{IC}_{50}>100 \mu \mathrm{M}\right)$. In addition, these compounds have weak antimalarial activity with $\mathrm{IC}_{50}$ values ranging from 120 to $190 \mu \mathrm{M}$. In a later study, eight diterpenoid dimers with the same skeleton as aphadilactone A, namely aphanamenes C-F and K-M (143-150), were isolated from the root barks of A. grandifolia [8]. In this study, other six diterpenoid dimers with a 2,2-dimethylfuran-3(2 $\mathrm{H})$-one ring and two substituents attached at the meso-position, namely aphanamenes G-J, $\mathrm{O}$ and $\mathrm{P}$ 


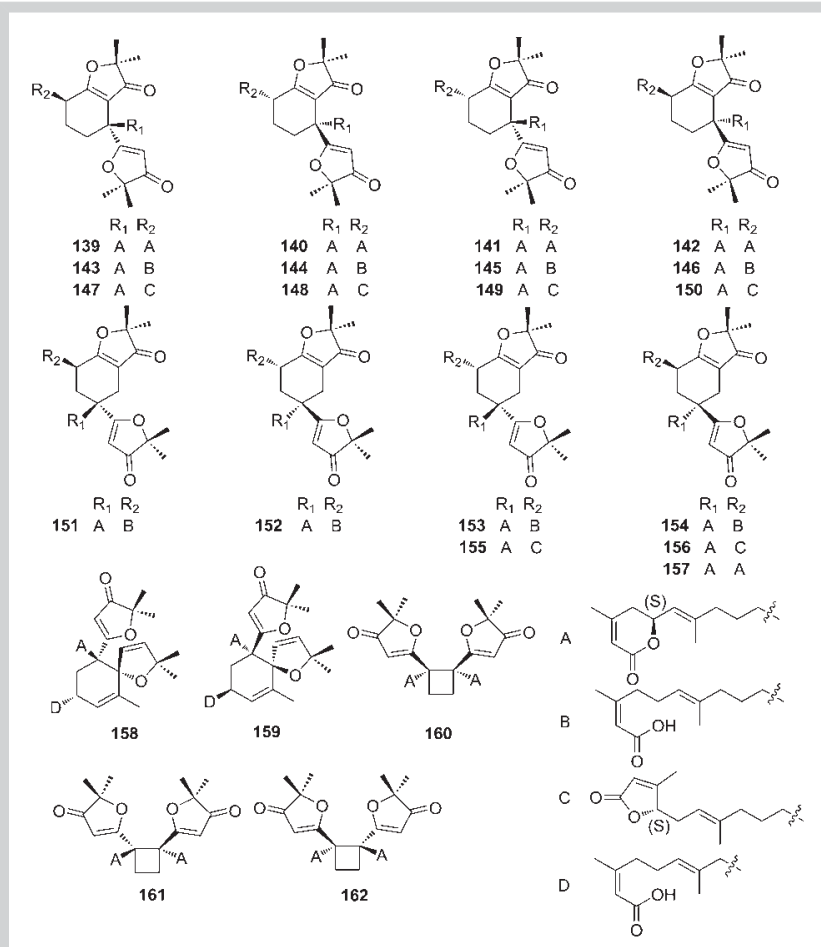

Fig. 15 Diterpenoid dimers from the family Meliaceae.

(151-156), were identified [8]. The structures of these compounds were elucidated by spectroscopic analysis, and their absolute configurations were determined using the $\mathrm{CD}$ exciton chirality method. As shown in a further study, these compounds exhibited significant inhibition of LPS-induced NO production in RAW264.7 macrophages, with $\mathrm{IC}_{50}$ values ranging from 7.75 to $19.31 \mu \mathrm{M}$. The isolation and structural elucidation of aphanamene B (157) was reported as part of an investigation of A. grandifolia [95]. This compound shares the same skeleton with aphanamene G. Aphanamene A (158) was also reported in this study and found to possess a spiro 2,2-dimethyl dihydroxyfuran ring on the cyclohexene ring [95]. It was proposed to be formed through a different $[4+2]$ cycloaddition reaction. Both structures were elucidated by spectroscopic analysis, and the absolute configuration of aphanamene A was determined by ECD calculations. These two compounds inhibited LPS-induced NO production in RAW264.7 cells with $\mathrm{IC}_{50}$ values of 9.72 and $7.98 \mu \mathrm{M}$, respectively. Recently, a chemical investigation into the minor constituents of $A$. grandifolia yielded one diterpenoid dimer, namely aphadilactone I (159), which was found to be a diastereoisomer of aphanamene A [9]. Besides, three diastereomeric diterpenoid dimers, namely aphadilactones $E-G$ (160-162), were also isolated from this species and found to contain a new carbon skeleton incorporating a 1,1,2,2-tetrasubstituted cyclobutane moiety. Their structures and absolute configurations were fully established by comprehensive spectroscopic data analysis and ECD calculations. It was proposed that aphadilactones $E-G$ were formed through a $[2+2]$ cycloaddition reaction in a head-to-head and tail-to-tail way. Aphadilactones $\mathrm{E}$ and $\mathrm{F}$ exhibited remarkable antimalarial activity with $\mathrm{IC}_{50}$ values of $1.03 \pm 0.13$ and $2.86 \pm 0.47 \mu \mathrm{M}$, respectively. These dimers could be considered as taxonomic markers of the species $A$. grandifolia.

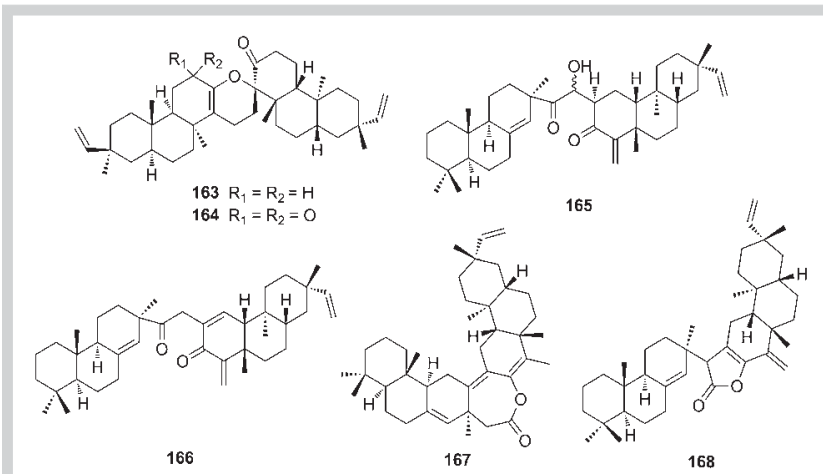

Fig. 16 Diterpenoid dimers from the family Rhizophoraceae.

\section{Family Rhizophoraceae}

The occurrence of diterpenoid dimers in the family Rhizophoraceae was only reported from the mangrove plant Ceriop tagal. At present, six dolabrane-type dimers have been isolated ( Fig. 16). By means of extensive spectroscopic analysis and single crystal X-ray diffraction, two dolabrane-type dimers, namely tagalsins I (163) and J (164), were identified. They represent the first examples of diterpenoid dimers from the family Rhizophoraceae [96]. In later studies, four dimers, namely tagalsins L-N (165-167) and 8(14)-enyl-pimar-2'(3')-en-4'(18')-en-15'(16')endolabr-16,15,2',3'-oxoan-16-one (168), were isolated from the roots of $C$. tagal $[97,98]$. 8(14)-enyl-pimar-2'(3')-en-4'(18')-en$15^{\prime}\left(16^{\prime}\right)$-endolabr-16,15,2',3'-oxoan-16-one exhibited antifouling activity against cyprid larvae (Balanus albicostatus) of the barnacle without significant toxicity. Dolabrane-type dimers could be considered as taxonomic markers of the species $C$. tagal. The stem barks of Xylopia acutiflora yielded a dimeric diterpene derived via Diels-Alder condensation of kaurene and labdane monomers. The structure of the dimer, which has been given the trivial name acutifloric acid, was assigned on the basis of detailed spectroscopic analysis.

\section{Family Taxaceae}

The isolation and structure elucidation of grandione (169) ( Fig. 17) was reported in the course of an investigation of Chinese specimens of Torreya grandis [99]. Grandione is formed by two icetexanoid units linked via a hetero-Diels-Alder dimerization reaction and shares the same skeleton as obtusinone D (112). Grandione represents the first and the only example of a linearly fused icetexanoid dimer from the family Taxaceae. Diabietane ether (170) ( $\odot$ Fig. 17), an abietanoid dimer connected by an ether linkage, was isolated from the needles of Taxus cuspidata [100].

\section{Family Velloziaceae}

An unusual bis-diterpenoid diacid, bismagdalenic acid (171) ( Fig. 17), was isolated from the hexane extract of the Brazilian plant Vellozia magdalenae [101]. Bismagdalenic acid is a dimer formed via a Diels-Alder condensation of magdalenic acid and a regular labdane diterpenoid, cis-ozic acid. This is the first report of the isolation of diterpenoid dimer from the family Velloziaceae. 


\section{Family Zingiberaceae}

The rhizomes of Alpinia pahangensis yielded the labdanoid dimer pahangensin C (172) (O Fig. 17) [102]. This dimer is formed via an ester bond between C-15 and C-15'. The structure of pahangensin C was elucidated by spectroscopic methods including $1 \mathrm{D}$ and 2D NMR and LCMS-IT (ion trap)-TOF analyses. It is the only diterpenoid dimer reported from the family Zingiberaceae.

\section{Diterpenoid Dimers from Fungi, Liverworts and Gorgonian}

A few diterpenoid dimers have been reported from sources other than plants, including fungi, liverworts and a gorgonian. These groups of organisms could be potential sources of novel diterpenoid dimers with promising biological activities and are worth further investigation in the future.

\section{Fungi (family Psathyrellaceae)}

Radianspene M (173) ( $\odot$ Fig. 18), a guanacastane-type diterpenoid dimer, was isolated from a fermentation of the M65 strain of the higher fungus Coprinus radians [103]. This is the first report of a diterpenoid dimer from fungi and provides new opportunities to investigate the dimerization mechanisms of diterpenoids as fungi are much easier to be manipulated in the laboratory through cultivation than plants.

\section{Liverworts (family Scapaniaceae)}

Two labdanoid dimers, namely scapaundulins A and B (174 and 175) (○ Fig. 18), were isolated from the diethyl ether extract of the Japanese liverworts Scapania undulata [104]. Their structures were characterized by spectroscopic techniques, especially 2D NMR and mass spectrometry. Two identical labdanoid units are connected via ester linkages in scapaundulin $\mathrm{A}$, or hemiacetal linkages in scapaundulin B, from C-8 of one subunit to C-11 of the other subunit. The structures of scapaundulins possess a $C_{2}$ axis of symmetry.

\section{Gorgonian (family Gorgoniidae)}

A chemical study of the hexane extract of the Caribbean gorgonian Antillogorgia bipinnata collected in San Andre's Island, Colombia, led to the isolation of an unprecedented heptacyclic diterpenoid dimer, namely bisersolanolide (176) (O Fig. 18) [105]. The structure of this secondary metabolite was established by spectroscopic studies including 2D NMR, IR, UV, and accurate mass measurements, and was further confirmed by synthesis. Bisersolanolide is the first diterpenoid dimer found to contain two cembranoid units. The generation of the 2,3-dihydro-4H-pyran ring is proposed to occur via a Diels-Alder coupling of two units of gersolane diterpenoids.

\section{Synthesis}

$\nabla$

Due to their high structural diversity and their biological activities, diterpenoids have attracted remarkable attention from a synthetic perspective. In contrast, only few successful total syntheses of diterpenoid dimers have been reported.

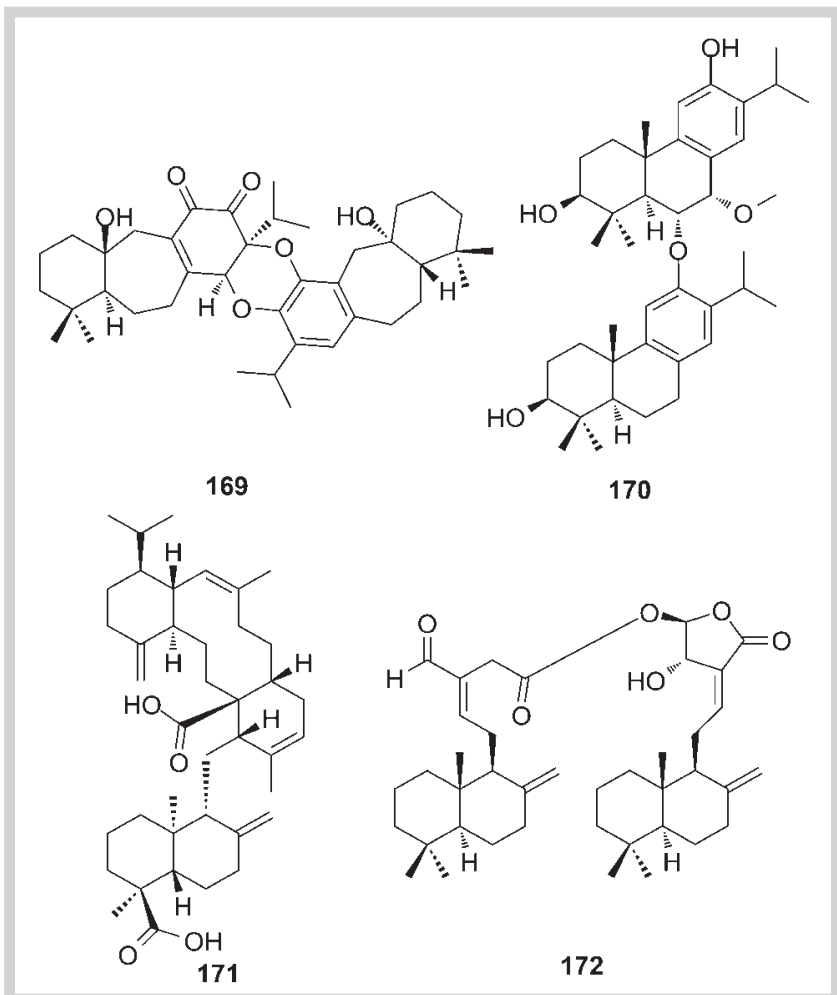

Fig. 17 Diterpenoid dimers from the families Taxaceae, Velloziaceae and Zingiberaceae.

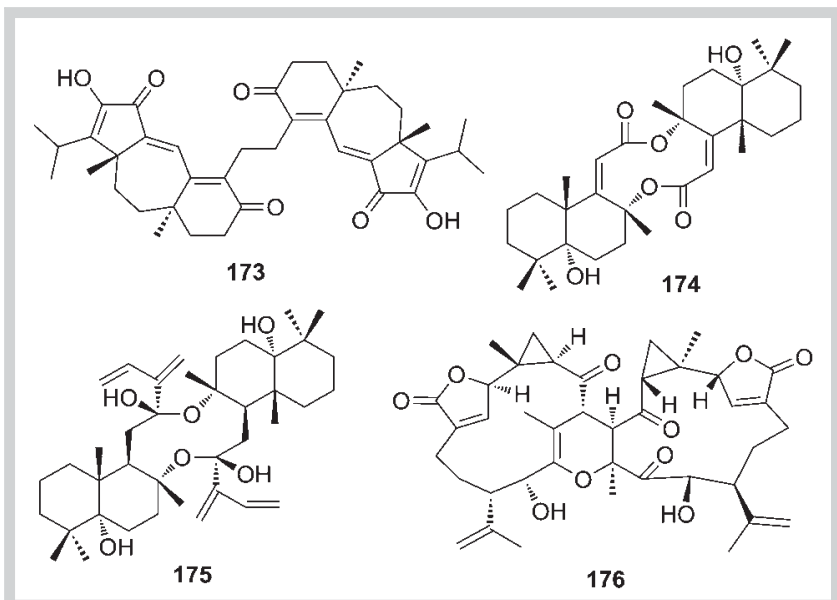

Fig. 18 Diterpenoid dimers from the families Psathyrellaceae, Scapaniaceae and Gorgoniidae.

\section{Synthesis of grandione}

Grandione (169) is a unique icetexanoid dimer. In 2005, Kurihara's group [106] first reported the partial synthesis of grandione from demethylsalvicanol via the solid state hetero-Diels-Alder type dimerization reaction. Three years later, Majetich's group [107] reported the total synthesis of (+)-grandione from benzyl bromide (177) and 6,6-dimethyl-1,3-cyclohexadione (178). The authors developed a two-step process to convert the achiral enone 179 into the $5 S$ alkene 180 (○ Fig. 19). Next, the authors took advantage of Kelecom's approach to convert alkene $\mathbf{1 8 0}$ into 
alcohol 181 [108]. The epoxidation of the C-1, C-10-trisubstituted double bond occurred from the $\beta$-face of 180 , and the subsequent opening of this epoxide with LAH introduced a $\beta$-oriented tertiary alcohol at C-10 ( $\odot$ Fig. 19). To avoid the solid state heteroDiels-Alder reaction, the authors carried out the cycloaddition in water at $50^{\circ} \mathrm{C}$ overnight, which produced (+)-grandione in good yield ( Fig. 19).

\section{Synthesis of aphadilactones}

Shortly after the isolation of aphadilactones A-D (139-142), a study on the total synthesis of these diterpenoid dimers was reported [13]. A proposed biosynthetic pathway of aphadilactones was put forward by Yue's group, in which the S-dienelactone 184 (๑ Fig. 20) served as a common biosynthetic precursor to these dimers [7]. The diastereomeric aphadilactones A-D were obtained in comparable amounts from the natural source, strongly suggesting that the final [4+2] dimerization was a non-enzymatically catalyzed process. The total syntheses of aphadilactones A-D were accomplished in eleven steps starting from the commercially available 1-methoxy-3-methylbuta-1,2-diene (182) and but-2-y-nal (183) ( Fig. 20). The S-dienelactone 184 reacted with BHT (butylated hydroxytoluene) in toluene at $170^{\circ}$ C for 17 hours to form aphadilactones A-D (approx. $1: 1: 1: 1$ ) through the bioinspired [4+2] dimerization/1,3 $\sigma$-hydrogen migration (๑ Fig. 20).

\section{Synthesis of taiwaniadduts}

A few members of taiwaniaquinoids, namely taiwaniadducts A-J, possess a characteristic Diels-Alder cycloadduct scaffold. In 2014, Li's group [109] carried out the first total synthesis of taiwaniadducts B-D, which took advantage of an Iridium-catalyzed asymmetric polyene cyclization in the synthesis of the two key fragments, namely taiwaniaquinone $\mathrm{F}$ (185) and methyl trans-ozitate (186). Then, the dimerization reaction was carried out with $\mathrm{Er}$ $(\text { fod })_{3}$ under neat conditions and elevated temperature to produce the cycloadduct 187 (52\% yield) and its regioisomer 188 ( $21 \%$ yield) but no other positional or diastereomeric isomers (- Fig. 21). The site selectivity toward the C-8 olefin over the C12 olefin may be attributable to the bulky isopropyl and the electron-donating methoxyl that make the latter olefin a worse dienophile. The facial selectivity may arise from the steric effect of the axial C-20 methyl group. Both cycloadducts were subjected to a three-step sequence of oxidation to furnish taiwaniadducts $B$ and $\mathrm{C}$. $\mathrm{Me}_{2} \mathrm{AlCl}$-mediated carbonyl-ene reaction formed taiwaniadduct D ( $91 \%$ yield) (๑ Fig. 21 ).

\section{Conclusions}

$\nabla$

As illustrated in this review, naturally occurring diterpenoid dimers have become an important research area in the field of natural products. There have been around 90 publications focusing on chemistry of diterpenoid dimers during the period covered by this review (1981 to January 2016). Up-to-date, 176 diterpenoid dimers have been described, most of which are from higher plants. As shown in 0 Table 1, the family Lamiaceae contributes the greatest number of diterpenoid dimers (60 compounds), and the families Meliaceae (23 compounds) and Cupressaceae (22 compounds) have also afforded numerous compounds. In contrast, only a few examples of diterpenoid dimers have been isolated from fungi, liverworts or marine animals, which might be due to the limited availability of these natural re-

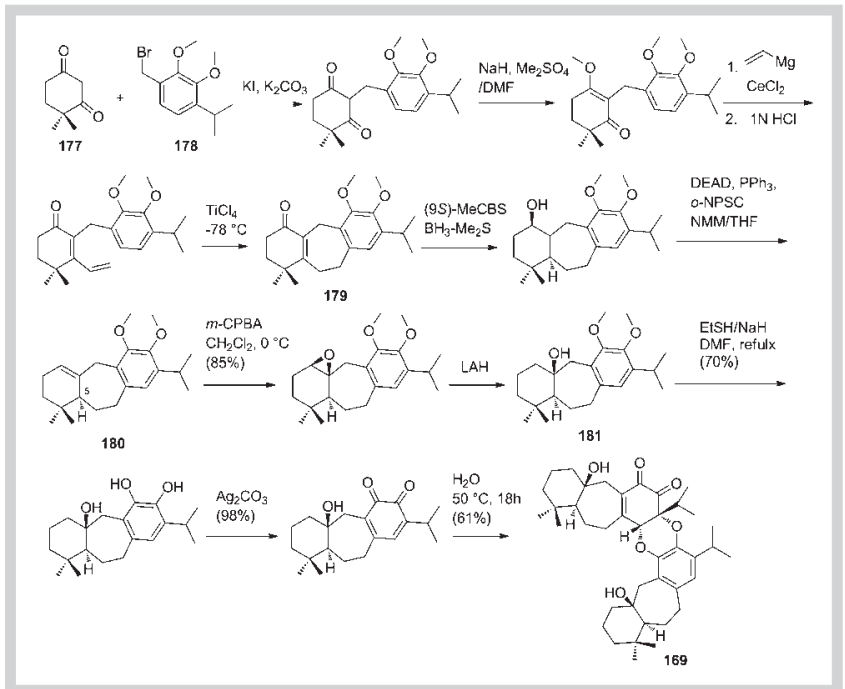

Fig. 19 Majetich's synthesis of (+)-grandione.

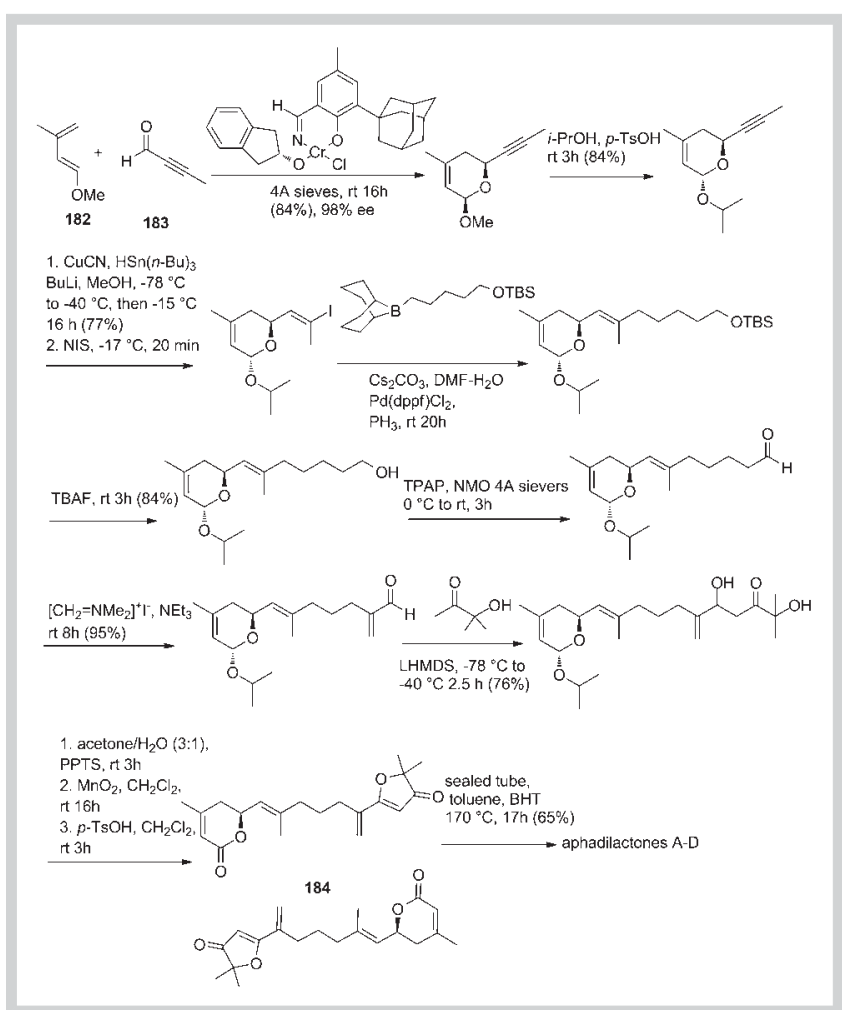

Fig. 20 Nan's synthesis of aphadilactones A-D (139-142).

sources. These organisms are believed to be promising materials for identifying novel diterpenoid dimers and eventually developing lead compounds.

There is a great structural diversity of diterpenoid dimers. As highlighted in this review, diterpenoid dimers can be classified into one of the following skeletons: kaurane-type, abietane-type, nemorallisin-type, labdane-type, clerodane-type, cassane-type, dolabrane-type, pimarane-type, icetexane-type, guanacastanetype, cembrane-type, rosane-type, or a combination of two from the above structural types. With 44 compounds the kaurane-type 


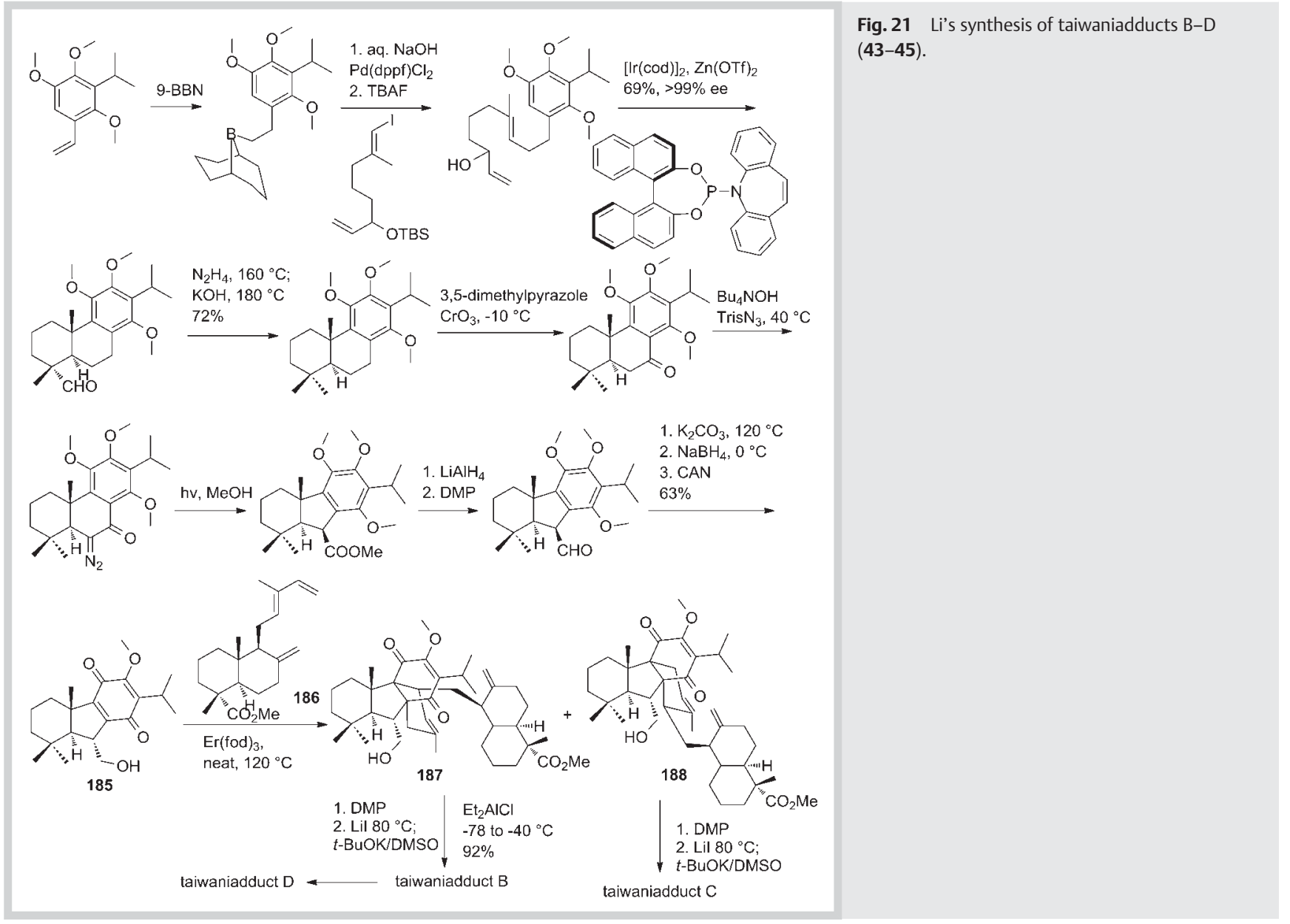

dimers contribute the greatest proportion. Most of the diterpenoid dimers are homodimers formed by two units of the same skeleton. Only 23 compounds are heterodimers containing two units of different skeletons. Three dimers composed of abietanetype and kaurane-type units, and four dimers composed of totarane-type and labdane-type units have been identified from plants of the family Lamiaceae. Besides, eight dimers with abietane-type and labdane-type units, and eight compounds with kaurane-type and labdane-type units have been found from plants of the families Cupressaceae and Annonaceae, respectively.

The linkages of diterpenoid dimers include single $\mathrm{C}-\mathrm{C}$ bonds, ether bonds, ester bonds and ring moieties. Enzyme-catalyzed Diels-Alder cycloaddition reaction is proposed to be a major mechanism involved in the synthesis of diterpenoid dimers. In addition enzyme-mediated Michael addition or aldol condensation is also proposed to form $\mathrm{C}-\mathrm{C}$ linkages in diterpenoid dimers. At present, there is no direct evidence confirming the proposed biosynthetic pathways of diterpenoid dimers and the putative natural Diels-Alderase still remains unknown. Increased efforts should be made in the future to elucidate the key enzymes and individual steps of the biosynthetic pathway of diterpenoid dimers.

Diterpenoid dimers have been reported with various bioactivities, including cytotoxic, anti-inflammatory, anti-microbial, anti-malarial, and anti-fouling effects. However, all these studies were carried out in in vitro assays. No in vivo animal studies or clinical trials have been conducted to evaluate the therapeutic ef- fects of diterpenoid dimers. Moreover, due to low amounts, most diterpenoid dimers have never been biologically tested. Further investigations should be performed in the future.

The studies summarized in this review confirm the potential of diterpenoid dimers for the discovery of novel pharmaceutical agents. It is hoped that chemists, pharmacologists and biologists will intensify research efforts on these complex secondary metabolites as a potential source of novel bioactive lead compounds.

\section{Acknowledgments}

$\nabla$

Financial support by the Research Fund of University of Macau (MYRG2014-00020-ICMS-QRCM and MYRG2015-00153-ICMSQRCM) and the Science and Technology Development Fund of Macau (120/2013/A3) is gratefully acknowledged.

\section{Conflict of Interest}

The authors declare no competing financial interest.

\section{References}

1 Hanson JR. Diterpenoids of terrestrial origin. Nat Prod Rep 2015; 32: 1654-1663

2 Vasas A, Hohmann J. Euphorbia diterpenes: isolation, structure, biological activity, and synthesis (2008-2012). Chem Rev 2014; 114: 85798612 
3 Gonzalez MA. Aromatic abietane diterpenoids: their biological activity and synthesis. Nat Prod Rep 2015; 32: 684-704

4 Cragg GM. Paclitaxel (Taxol): a success story with valuable lessons for natural product drug discovery and development. Med Res Rev 1998; 18: $315-331$

5 Siebert DJ. Salvia divinorum and salvinorin A: new pharmacologic findings. J Ethnopharmacol 1994; 43: 53-56

6 Roth BL, Baner K, Westkaemper R, Siebert D, Rice KC, Steinberg S, Ernsberger $P$, Rothman $R B$. Salvinorin A: a potent naturally occurring nonnitrogenous kappa opioid selective agonist. Proc Natl Acad Sci U S A 2002; 99: 11934-11939

7 Liu J, He XF, Wang GH, Merino EF, Yang SP, Zhu RX, Gan LS, Zhang H, Cassera $M B$, Wang HY, Kingston DG, Yue JM. Aphadilactones A-D, four diterpenoid dimers with DGAT inhibitory and antimalarial activities from a Meliaceae plant. J Org Chem 2014; 79: 599-607

8 Zhang HJ, Zhang YM, Luo JG, Luo J, Kong LY. Anti-inflammatory diterpene dimers from the root barks of Aphanamixis grandifolia. Org Biomol Chem 2015; 13: 7452-7458

9 Zhang H, Liu J, Gan LS, Dalal S, Cassera MB, Yue JM. Antimalarial diterpenoid dimers of a new carbon skeleton from Aphanamixis grandifolia. Org Biomol Chem 2016; 14: 957-962

10 Wang WX, Zhu JJ, Zou YK, Hong ZL, Liu ST, Li M, Huang Y, Xiong J, Zhao Y, Yang GX, Xia G, Hu JF. Trichotomone, a new cytotoxic dimeric abietanederived diterpene from Clerodendrum trichotomum. Tetrahedron Lett 2013; 54: 2549-2552

11 Zhang JY, Abdel-Mageed WM, Liu MM, Huang P, He WN, Li L, Song FH, Dai HQ Liu XT, Liang JY, Zhang LX. Caesanines A-D, new cassane diterpenes with unprecedented $\mathrm{N}$ bridge from Caesalpinia sappan. Org Lett 2013; 15: 4726-4729

12 Zi J, Mafu S, Peters RJ. To gibberellins and beyond! Surveying the evolution of (di)terpenoid metabolism. Annu Rev Plant Biol 2014; 65: 259286

13 Yin JP, Gu M, Li Y, Nan FJ. Total synthesis of aphadilactones A-D. J Org Chem 2014; 79: 6294-6301

14 Oikawa H, Tokiwano T. Enzymatic catalysis of the Diels-Alder reaction in the biosynthesis of natural products. Nat Prod Rep 2004; 21 : 321352

15 Oikawa H, Katayama K, Suzuki Y, Ichihara A. Enzymatic-activity catalyzing exo-selective Diels-Alder reaction in solanapyrone biosynthesis. Chem Commun 1995; 1321-1322

16 Katayama K, Kobayashi T, Oikawa H, Honma M, Ichihara A. Enzymatic activity and partial purification of solanapyrone synthase: first enzyme catalyzing Diels-Alder reaction. Biochim Biophys Acta 1998; 1384: 387-395

17 Auclair K, Sutherland A, Kennedy J, Witter DJ, Van den Heever JP, Hutchinson $C R$, Vederas JC. Lovastatin nonaketide synthase catalyzes an intramolecular Diels-Alder reaction of a substrate analogue. J Am Chem Soc 2000; 122: 11519-11520

18 Ose T, Watanabe K, Mie T, Honma M, Watanabe H, Yao M, Oikawa H, Tanaka I. Insight into a natural Diels-Alder reaction from the structure of macrophomate synthase. Nature 2003; 422: 185-189

19 Xu JA, Deng QL, Chen JG, Houk KN, Bartek J, Hilvert D, Wilson IA. Evolution of shape complementarity and catalytic efficiency from a primordial antibody template. Science 1999; 286: 2345-2348

$20 \mathrm{Kim}$ SP, Leach AG, Houk KN. The origins of noncovalent catalysis of intermolecular Diels-Alder reactions by cyclodextrins, self-assembling capsules, antibodies, and RNAses. J Org Chem 2002; 67: 4250-4260

21 Siegel JB, Zanghellini A, Lovick HM, Kiss G, Lambert AR, Clair JLS, Gallaher $J L$, Hilvert D, Gelb MH, Stoddard BL, Houk KN, Michael FE, Baker D. Computational design of an enzyme catalyst for a stereoselective bimolecular Diels-Alder reaction. Science 2010; 329: 309-313

22 Wu JZ, Ruan HL, Yao NH, Sun HD, Zhao QS, Morizane C, Iida A, Fujita T. Structural elucidation and synthesis of fritillebinide $A$ from bulbs of Fritillaria ebeiensis. Acta Pharm Sin 1999; 34: 600-604

23 Zhao Y, Huang SX, Xiao WL, Ding LS, Pu JX, Li X, Yang LB, Sun HD. Diterpenoids from Isodon pharicus. Tetrahedron Lett 2009; 50: 2019-2023

24 Matsuda T, Kuroyanagi M, Sugiyama S, Umehara K, Ueno A, Nishi K. Cell differentiation-inducing diterpenes from Andrographis paniculata Nees. Chem Pharm Bull (Tokyo) 1994; 42: 1216-1225

25 Hasan CM, Healey TM, Waterman PG. Chemical studies in the Annonaceae .13. acutifloric acid-a diterpene dimer from the stem bark of Xylopia acutiflora. Phytochemistry 1985; 24: 192-194

26 Vilegas W, Felicio JD, Roque NF, Gottlieb HE. Diterpenic adducts from Xylopia Species. Phytochemistry 1991; 30: 1869-1872
27 Takahashi JA, Boaventura MAD, Bayma JD, Oliveira AB. Frutoic acid, a dimeric kaurane diterpene from Xylopia frutescens. Phytochemistry 1995; 40: 607-609

28 Moreira IC, Roque NF, Lago JHG. Diterpene adducts from branches of Xylopia emarginata. Biochem Syst Ecol 2006; 34: 833-837

29 Martins D, Hamerski L, Alvarenga SAV, Roque NF. Labdane dimers from Xylopia aromatica. Phytochemistry 1999; 51: 813-817

30 Yang NY, Tian LJ, Meng ZM, Han Y. A new diterpenoid dimer from Annona glabra. Chin Chem Lett 2003; 14: 58-61

31 Chen CH, Hsieh TJ, Liu TZ, Chern CL, Hsieh PY, Chen CY. Annoglabayin, a novel dimeric kaurane diterpenoid, and apoptosis in Hep G2 cells of annomontacin from the fruits of Annona glabra. J Nat Prod 2004; 67: 1942-1946

32 Labbe C, Castillo M, Hernandez M. Diterpenoids from Baccharis lejia. Phytochemistry 1991; 30: 1607-1611

33 Chamy MC, Piovano M, Garbarino JA, Gambaro V, Miranda C. Diterpenoids from Calceolaria species 3. foliosate, a bis-diterpene and 9-epient-7,15-isopimaradiene derivatives from Calceolaria foliosa. Phytochemistry $1989 ; 28$ : 571-574

34 Piovano M, Chamy MC, Garbarino JA, Gambaro V. Diterpenoids from Calceolaria species 4.9-epi-ent-7,15-isopimaradiene derivatives from Calceolaria glandulosa. Phytochemistry 1989; 28: 2844-2845

35 Chamy MC, Piovano M, Garbarino JA, Miranda C, Gambaro V. Diterpenoids from Calceolaria species 5. diterpenes from Calceolaria lepida. Phytochemistry 1990; 29: 2943-2946

36 Chamy MC, Piovano M, Garbarino JA, Gambaro V. Diterpenoids from Calceolaria species 10. diterpenes from Calceolaria polifolia. Phytochemistry 1991; 30: 3365-3368

37 Silva P, Chamy MC, Piovano M, Garbarino JA. Diterpenoids from Calceolaria petioalaris 14. diterpenoids from Calceolaria species. Phytochemistry $1993 ; 34:$ 449-451

38 Garbarino JA, Molinari A. Diterpenoids from Calceolaria species 9. labdane diterpenes from Calceolaria densifolia. J Nat Prod 1992; 55: 744 747

39 Braca A, Abdel-Razik AF, Mendez J, Morelli I. A new kaurane diterpene dimer from Parinari campestris. Fitoterapia 2005; 76: 614-619

40 Hanari N, Yamamoto H, Ooi T, Kusumi T, Kuroda K. A new diterpene dimer from the bark of Chamaecyparis obtusa. J Wood Sci 2001; 47: 36-40

41 Arihara S, Umeyama A, Bando S, Imoto S, Ono M, Tani M, Yoshikawa K. A new abietane and two dimeric abietane diterpenes from the black heartwood of Cryptomeria japonica. Chem Pharm Bull (Tokyo) 2004; 52: 354-358

42 Hsieh CL, Tseng MH, Kuo YH. Formosadimers A, B, and C from the bark of Calocedrus macrolepis var. formosana. Chem Pharm Bull (Tokyo) 2005; 53: $1463-1465$

43 Hsieh CL, Shiu LL, Tseng MH, Shao YY, Kuo YH. Calocedimers A, B, C, and $\mathrm{D}$ from the bark of Calocedrus macrolepis var. formosana. J Nat Prod 2006; 69: 665-667

$44 \mathrm{Ku}$ YH, Yu MT. Diterpenes from the heartwood of Juniperus formosana Hay var concolor Hay. Chem Pharm Bull (Tokyo) 1996; 44: 1431-1435

45 Kuo YH, Chen $\mathrm{CH}$, Wein YS. New dimeric monoterpenes and dimeric diterpenes from the heartwood of Chamaecyparis obtusa var. formosana. Helv Chim Acta 2002; 85: 2657-2663

46 Hou XF, Yao S, Mandi A, Kurtan T, Tang CP, Ke CQ Li XQ Ye Y. Bicunningines $\mathrm{A}$ and $\mathrm{B}$, two new dimeric diterpenes from Cunninghamia lanceolata. Org Lett 2012; 14: 460-463

47 Lin WH, Fang JM, Cheng YS. Diterpenes and related cycloadducts from Taiwania cryptomerioides. Phytochemistry 1996; 42: 1657-1663

48 Lin WH, Fang JM, Cheng YS. Cycloadducts of terpene quinones from Taiwania cryptomerioides. Phytochemistry 1997; 46: 169-173

49 Pan ZH, Ning DS, Wu XD, Huang SS, Li DP, Lv SH. New clerodane diterpenoids from the twigs and leaves of Croton euryphyllus. Bioorg Med Chem Lett 2015; 25: 1329-1332

50 Thuong PT, Thi HMP, Thi VTL, Dao TT, Dang TT, Nguyen QT, Oh WK. Symmetric dimers of ent-kaurane diterpenoids with cytotoxic activity from Croton tonkinensis. Bioorg Med Chem Lett 2012; 22: 1122-1124

51 Fu GM, Qin HL, Yu SS, Yu BY. Yuexiandajisu D, a novel 18-nor-rosanetype dimeric diterpenoid from Euphorbia ebracteolata Hayata. J Asian Nat Prod Res 2006; 8: 29-34

52 Zhou TX, Bao GH, Ma QG, Qin GW, Che CT, Lv Y, Wang C, Zheng QT. Langduin $C$, a novel dimeric diterpenoid from the roots of Euphorbia fischeriana. Tetrahedron Lett 2003; 44: 135-137 
53 Zhang BY, Wang H, Luo XD, Du ZZ, Shen JW, Wu HF, Zhang XF. Bisyinshanic acids $A$ and $B$, two novel diterpene dimers from the toots of $E u$ phorbia yinshanica. Helv Chim Acta 2012; 95: 1672-1679

54 Tene M, Tane P, Tamokou JD, Kuiate JR, Connolly JD. Degraded diterpenoids from the stem bark of Neoboutonia mannii. Phytochemistry Lett 2008; 1: 120-124

55 Tane P, Bergquist KE, Tene M, Ngadjui BT, Ayafor JF, Sterner O. Cyclodione, an unsymmetrical dimeric diterpene from Cylicodiscus gabunensis. Tetrahedron 1995; 51: 11595-11600

56 Miyagawa T, Ohtsuki T, Koyano T, Kowithayakorn T, Ishibashi M. Cassaine diterpenoid dimers isolated from Erythrophleum succirubrum with TRAIL-resistance overcoming activity. Tetrahedron Lett 2009; 50: 4658-4662

57 Du D, Qu J, Wang JM, Yu SS, Chen XG, Xu S, Ma SG, Li Y, Ding GZ, Fang L. Cytotoxic cassaine diterpenoid-diterpenoid amide dimers and diterpenoid amides from the leaves of Erythrophleum fordii. Phytochemistry 2010; 71: 1749-1755

58 Hung TM, Cuong TD, Kim JA, Lee JH, Woo MH, Min BS. In vitro apoptotic effect of cassaine-type diterpene amides from Erythrophleum fordii on PC-3 prostate cancer cells. Bioorg Med Chem Lett 2014; 24: 4989-4994

59 Rustaiyan A, Mossleminkupaii MH, Papastergiou F, Jakupovic J. Persianone, a dimeric diterpene from Ballota aucheri. Phytochemistry 1995; 40: $875-879$

60 Pandey R, Verma RK, Gupta MM. Neo-clerodane diterpenoids from Clerodendrum inerme. Phytochemistry 2005; 66: 643-648

61 Shen XY, Isogai A, Furihata K, Sun HD, Suzuki A. Maoecrystal M-a naturally-occurring symmetrical ent-kaurane dimer from Rabdosia eriocalyx. Phytochemistry 1994; 35: 725-729

62 Yang JH, Wang WG, Du X, He F, Zhang HB, Li XN, Li Y, Pu JX, Sun HD. Heterodimeric ent-kauranoids from Isodon tenuifolius. J Nat Prod 2014; 77: 2444-2453

63 Yang LB, Yang J, Li LM, Lei C, Zhao Y, Huang SX, Xiao WL, Han QB, Pu JX, Sun HD. Symmetric and asymmetric ent-kaurane dimers isolated from Isodon japonicus. Tetrahedron Lett 2008; 49: 3574-3577

64 Han QB, Lu Y, Wu L, He ZD, Qiao CF, Xu HX, Zheng QT, Sun HD. An asymmetric ent-kauranoid dimer from Isodon rubescens var. lushanensis. Tetrahedron Lett 2005; 46: 5373-5375

65 Huang SX, Xiao WL, Li LM, Li SH, Zhou Y, Ding LS, Lou LG, Sun HD. Bisrubescensins A-C: three new dimeric ent-kauranoids isolated from Isodon rubescens. Org Lett 2006; 8: 1157-1160

66 Hong SS, Lee SA, Lee C, Han XH, Choe S, Kim N, Lee D, Lee CK, Kim Y, Hong $J T$, Lee $M K$, Hwang BY. Dimeric ent-kaurane diterpenoids from Isodon excisus. J Nat Prod 2011; 74: 2382-2387

67 Han $Q B$, Lu Y, Zhang LL, Zheng OT, Sun HD. Novel ent-kaurane dimers from Isodon rubescens var. rubescens. Tetrahedron Lett 2004; 45 : 2833-2837

68 Han QB, Li RT, Zhang JX, Sun HD. New ent-abietanoids from Isodon rubescens. Helv Chim Acta 2004; 87: 1007-1015

69 Huang SX, Pu JX, Xiao WL, Li LM, Weng ZY, Zhou Y, Han QB, Peng SL, Ding LS, Lou LG, Sun HD. ent-Abietane diterpenoids from Isodon rubescens var. rubescens. Phytochemistry 2007; 68: 616-622

70 Huang B, Xiao CJ, Huang ZY, Tian XY, Cheng X, Dong X, Jiang B. Hispidanins A-D: four new asymmetric dimeric diterpenoids from the rhizomes of Isodon hispida. Org Lett 2014; 16: 3552-3555

71 Marques CG, Pedro M, Simoes MF, Nascimento MS, Pinto MM, Rodriguez $B$. Effect of abietane diterpenes from Plectranthus grandidentatus on the growth of human cancer cell lines. Planta Med 2002; 68: 839-840

72 Suresh G, Babu KS, Rao MSA, Rao VRS, Yadav PA, Nayak VL, Ramakrishna $S$. Premnalatifolin A, a novel dimeric diterpene from Premna latifolia Roxb. Tetrahedron Lett 2011; 52: 5016-5019

73 Salae AW, Boonnak N. Obtusinones D and E, linear and angular fused dimeric icetexane diterpenoids from Premna obtusifolia roots. Tetrahedron Lett 2013; 54: 1356-1359

74 Li M, Zhang JS, Chen MQ. A novel dimeric diterpene from Salvia prionitis. J Nat Prod 2001; 64: 971-972

$75 \mathrm{Xu}$ J, Chang J, Zhao M, Zhang JS. Abietane diterpenoid dimers from the roots of Salvia prionitis. Phytochemistry 2006; 67: 795-799

76 Gonzalez AG, Rodriguez CM, Luis JG. Diterpenes from the flowers of Salvia canariensis. Phytochemistry 1987; 26: 1471-1474

77 Xiao QL, Xia F, Yang XW, Liao Y, Yang LX, Wei YK, Li X, Xu G. New dimeric and seco-abietane diterpenoids from Salvia wardii. Nat Prod Bioprospect, advance online publication 8 April 2015; DOI: 10.1007/s13659015-0054-6
78 Choudhary MI, Hussain A, Ali Z, Adhikari A, Sattar SA, Ayatollahi SA, AlMajid AM. Diterpenoids including a novel dimeric conjugate from Salvia leriaefolia. Planta Med 2012; 78: 269-275

79 Hussain A, Adhikari A, Choudhary MI, Ayatollahi SA, Atta-ur-Rahman. New adduct of abietane-type diterpene from Salvia leriifolia Benth. Nat Prod Res, advance online publication 6 January 2016; DOI: 10.1080/14786419.2015.1115997

80 Fraga BM, Diaz CE, Lopez-Rodriguez M. Two novel abietane dimers from transformed root cultures of Salvia broussonetii. Tetrahedron Lett 2014; 55: 877-879

81 Christensen $K B$, Jorgensen $M$, Kotowska D, Petersen RK, Kristiansen $K$, Christensen LP. Activation of the nuclear receptor PPAR gamma by metabolites isolated from sage (Salvia officinalis L.). J Ethnopharmacol 2010; 132: 127-133

82 Bisio A, De Tommasi N, Romussi G. Diterpenoids from Salvia wagneriana. Planta Med 2004; 70: 452-457

83 Gao C, Han L, Zheng D, Jin HW, Gai CY, Wang JB, Zhang H, Zhang LR, Fu $H Z$. Dimeric abietane diterpenoids and sesquiterpenoid lactones from Teucrium viscidum. J Nat Prod 2015; 78: 630-638

84 Wu JZ, Morizane C, Iida A, Ueda SI, Zhou ZL, Xu M, Zhang M, Li RM, Fujita $T$. Structures of three new diterpenoids, fritillebic acid and fritillebins A and B, from bulbs of Fritillaria ebeiensis G. D. Yu et G. Q. Ji. Chem Pharm Bull (Tokyo) 1995; 43: 1448-1453

85 Wu JZ, Ruan HL, Zeng CL, Cheng HA, Zhang F, Zhao QS, Sun HD, Fujita T. Structures of two new diterpenoid dimers from bulbs of Fritillaria ebeiensis. J Asian Nat Prod Res 1999; 1: 251-257

86 Wu JZ, Wen YP, Ruan HL, Yao NH, Zhao QS, Sun HD, Morizane C, Iida A, Fujita T. Structural elucidations of two ent-kaurane dimers from bulbs of Fritillaria ebeiensis var. purpurea. J Asian Nat Prod Res 2000; 2 : 213-218

87 Wu JZ, Ruan HL, Yao NH, Zhao QS, Sun HD, Morizane C, Iida A, Fujita T. Structures of two diterpenoid dimers from bulbs of Fritillaria ebeiensis. J Asian Nat Prod Res 2000; 2: 161-167

88 Ruan HL, Zhang YH, Wu JZ, Sun HD, Fujita T. Two new diterpenoid dimers, fritillebinide $\mathrm{D}$ and $\mathrm{E}$, from bulbs of Fritillaria ebeiensis. J Asian Nat Prod Res 2002; 4: 309-314

89 Zhang HJ, Luo J, Shan SM, Wang XB, Luo JG, Yang MH, Kong LY. Aphanamenes A and B, two new acyclic diterpene [4+2]-cycloaddition adducts from Aphanamixis grandifolia. Org Lett 2013; 15: 5512-5515

90 Zhang Y, Lu Y, Mao L, Proksch P, Lin WH. Tagalsins I and J, two novel tetraterpenoids from the mangrove plant, Ceriops tagal. Org Lett 2005; 7: 3037-3040

91 Chen JD, Qiu Y, Yang ZW, Lin P, Lin YM. Dimeric diterpenes from the roots of the mangrove plant Ceriops tagal. Helv Chim Acta 2008; 91 : 2292-2298

92 Chen JD, Yi RZ, Lin YM, Feng DQ, Zhou HC, Wang ZC. Characterization of terpenoids from the root of Ceriops tagal with antifouling activity. Int J Mol Sci 2011; 12: 6517-6528

93 Galli B, Gasparrini F, Lanzotti V, Misiti D, Riccio R, Villani C, He GF, Ma $Z W$, Yin WF. Grandione, a new heptacyclic dimeric diterpene from Torreya grandis Fort. Tetrahedron 1999; 55: 11385-11394

94 Ni ZY, Wu YB, Dong M, Zhang ML, Wang YF, Sauriol F, Huo CH, Shi QW, $G u$ YC, Kiyota H, Cong B. Diabietane ether, a new dimeric abietane with an ether linkage from Taxus cuspidata Needles. Z Naturforsch B 2011; 66: 1083-1086

95 Pinto AC, Pizzolatti MG, Epifanio RDA, Frankmolle W, Fenical W. The isolation of novel diterpenoids, including a C-40 bis-diterpenoid, from the Brazilian plant Vellozia magdalenae (Velloziaceae). Tetrahedron 1997; 53: 2005-2012

96 Sivasothy Y, Ibrahim H, Paliany AS, Alias SA, Md Nor NR, Awang K. A new bis-labdanic diterpene from the rhizomes of Alpinia pahangensis. Planta Med 2013; 79: 1775-1780

97 Ou YX, Li YY, Qian XM, Shen YM. Guanacastane-type diterpenoids from Coprinus radians. Phytochemistry 2012; 78: 190-196

98 Yoshida T, Toyota M, Asakawa Y. Scapaundulins A and B, two novel dimeric labdane diterpenoids, and related compounds from the Japanese liverwort Scapania undulata (L) Dum. Tetrahedron Lett 1997; 38: $1975-1978$

99 Rodriguez $A D$, Shi JG. Isolation, structure elucidation, and synthesis of bisgersolanolide, a novel heptacyclic bis-diterpenoid from the gorgonian octocoral Pseudopterogorgia bipinnata. Org Lett 1999; 1: 337-340

100 Johnstone RW, Frew AJ, Smyth MJ. The TRAIL apoptotic pathway in cancer onset, progression and therapy. Nat Rev Cancer 2008; 8: 782-798

101 Obenhuber AH, Gianetti TL, Bergman RG, Arnold J. Regioselective [2 + 2 ] and $[4+2]$ cycloaddition reactivity in an asymmetric niobium(bisimi- 
do) moiety towards unsaturated organic molecules. Chem Commun 2015; $51: 1278-1281$

102 Gao WY, Zhang R, Jia W, Zhang J, Takaishi Y, Duan HQ. Immunosuppressive diterpenes from Veronicastrum sibiricum. Chem Pharm Bull (Tokyo) 2004; 52: 136-137

103 Uchida M, Miyase T, Yoshizaki F, Bieri JH, Ruedi P, Eugster CH. Isolation of 14-hydroxytaxodione from Plectranthus grandidentatus Gurke and of 7 new dimeric diterpenoids from Plectranthus grandidentatus, Plectranthus myrianthus and Coleus carnosus - structures of grandidone a, 7-epi-A, B, 7-epi-B, C, D and 7-epi-D. Helv Chim Acta 1981; 64: 2227-2250

104 Chen SK, Chen BY, Li H. Flora Reipublicae Popularis Sinicae (Zhongguo Zhiwu Zhi). Beijing: Science Press; 1997

105 Hu XM, Zhang WK, Song LR, Hu L, Zhang GZ, Xie ZW, Wang XT, Xu GJ, Xiao PG, Ling YK, Ding XL, Cao CL, Li YK, Yu WX, Hong X, Wang JH.
Chinese Materia Medica (Zhonghua Bencao). Shanghai: Shanghai Science and Technology Press; 1999

106 Aoyagi Y, Takahashi Y, Satake Y, Fukaya H, Takeya K, Aiyama R, Matsuzaki T, Hashimoto S, Shiina T, Kurihara T. Biomimetic synthesis of grandione from demethylsalvicanol via hetero-Diels-Alder type dimerization and structure revision of grandione. Tetrahedron Lett 2005; 46: 7885-7887

107 Majetich G, Zou G. Total synthesis of (-)-barbatusol, (+)-demethylsalvicanol, (-)-brussonol, and (+)-grandione. Org Lett 2008; 10: 81-83

108 Kelecom A. Isolation, structure determination, and absolute configuration of barbatusol, a new bioactive diterpene with a rearranged abietane skeleton from the Labiate Coleus barbatus. Tetrahedron 1983; 39: 3603-3608

109 Deng J, Zhou SP, Zhang WH, Li J, Li RF, Li A. Total synthesis of taiwaniadducts B, C, and D. J Am Chem Soc 2014; 136: 8185-8188 